\title{
Toplumsal Dayanışma Ağlarının Gazetecilikte Kullanımı: Sosyal Sermayenin Kamusal Habercilikteki Rolünün İncelenmesi*
}

\author{
Ahmet Biçer (Arş. Gör. Dr.) \\ Erciyes Üniversitesi İletişim Fakültesi \\ ahmetbicer@erciyes.edu.tr \\ ORCID: 0000-0001-7548-5450 \\ Mustafa Koçer (Doç. Dr.) \\ Erciyes Üniversitesi İletişim Fakültesi \\ mkacur@erciyes.edu.tr \\ ORCID: 0000-0002-7380-6684
}

\author{
Başvuru Tarihi: 01.10.2019 \\ Yayına Kabul Tarihi: 15.11.2019 \\ Yayınlanma Tarihi: 24.01.2020 \\ DOI: http://10.17680/erciyesiletisim.627824
}

\section{Öz}

Sosyal sermaye, bireysel ve toplumsal olmak üzere iki farklı gerçeklik düzleminde değerlendirilebilir. Bireysel düzlemde sosyal sermaye; aktörlerin sosyal ilişkilerinden elde ettikleri ve amaçları doğrultusunda kullandıkları bir kaynaktır. Toplumsal düzlemde ise; yaşanılan bölgedeki komşuluk ilişkilerinden yardımlaşma düşüncesine, sivil toplum kuruluşlarından dernekleşme faaliyetlerine kadar, bir dizi sivil katılım biçiminin toplumsal hayata sağladığı katkıları ifade eden bir kaynak olarak değerlendirilmektedir. Dolayısıyla çalışmada, sosyal yapılardan veya ilişkilerden elde edilen bir kaynak olan sosyal sermayeyi, gazetecilerin mesleki pratiklerinde kullanmaları gerektiği varsayılmıştır. $\mathrm{Bu}$ varsayımdan hareketle, gazetecilerin kamusal habercilik olanaklarında sosyal sermayenin rolünün incelenmesi amaçlanmıştır.

Çalışma amaçları doğrultusunda sosyal sermaye kavramsal olarak açıklanmış, gazetecilik alanıyla sosyal sermaye yaklaşımının arasındaki ilişkileri konu alan literatüre kısaca yer verilmiştir. Saha araştırmasında, gazetecilerin sosyal sermayeleri ve kamusal habercilik olanakları arasındaki ilişki incelenmiş, gazetecilerin sosyal çevreleriyle yakınlıkları ve etkileşimleri açısından sosyal sermaye ve kamusal habercilik olanaklarında oluşan farklılaşmalar araştırılmıştır. Ağırlıklı olarak İstanbul, Ankara ve İzmir'de çalışan gazeteciler olmak üzere, toplam 384 gazeteciyle anket çalışması gerçekleștirilmiştir. Elde edilen bulgular, araştırmaya katılan gazetecilerin sosyal sermayelerinin, algıladıkları kamusal habercilik olanakları üzerinde istatistiksel olarak anlamlı ve pozitif yönlü bir etkisinin bulunduğunu ortaya koymuştur. Ayrıca gazetecilerin sosyal çevreleriyle yakınlıkları ve etkileşim sayıları arttıkça, sosyal sermaye ve kamusal habercilik olanakları ortalamalarının arttığını gösteren bulgular tespit edilmiştir. Bu bağlamda sosyal sermayenin kamusal habercilik pratiklerinde önemli bir rolü bulunduğu, toplumsal dayanışma ve iletişim ağlarına katılımın toplum yanlısı gazetecilik pratiklerini kolaylaştırdığı anlaşılmıştır.

Anahtar Kelimeler: Gazetecilik, Sosyal Sermaye, Kamusal Habercilik.

\footnotetext{
* Bu çalışma, Erciyes Üniversitesi Sosyal Bilimler Enstitüsü'ne 2019 yılında sunulan "Toplumsal Dayanışma Ağlarının Gazetecilikte Kullanımı: Sosyal Sermayenin Kamusal Habercilikteki Rolünün İncelenmesi” başılılı doktora tez özetidir.
} 


\title{
The Use of Social Solidarity Networks in Journalism: Investigation on the Role of Social Capital in Public Journalism
}

\author{
Ahmet Biçer (Res. Asst. Ph.D.) \\ Erciyes University Faculty of Communication \\ ahmetbicer@erciyes.edu.tr \\ ORCID: 0000-0001-7548-5450 \\ Mustafa Koçer (Assoc. Prof. Dr.) \\ Erciyes University Faculty of Communication \\ mkacur@erciyes.edu.tr \\ ORCID: 0000-0002-7380-6684
}

Date Received: 01.10.2019

Date Accepted: 15.11.2019

Date Published: 24.01.2020

DOI: http://10.17680/erciyesiletisim.627824

\section{Abstract}

Social capital can be evaluated in two different reality aspects as individual and social. At the individual level, social capital is a resource derived from social relationships of actors and which they use for their purposes. At the social level, it is considered as a resource that expresses the contribution of several forms of civil participation to social life, from neighborhood relations in the area of living to mutual aids, from non-governmental organizations to association activities. Therefore, in the study it is assumed that journalists should use the social capital, which is a source derived from social structures and relations, in their professional practice. Considering this assumption, it is aimed to examine the role of social capital in the journalists' public journalism opportunities.

For the purposes of the study, social capital was conceptually explained and the literature on the relationship between journalism and social capital approach was briefly mentioned. In the field research, the relationship between the social capital of the journalists and their opportunities of public journalism was examined and the differences in their social capital and opportunities of public journalism in terms of their close relations and interactions with their social environments were investigated. The survey was conducted with a total of 384 journalists, mainly with the journalists working in Istanbul, Ankara and Izmir. The findings revealed that the social capital of the journalists participating in the study had a statistically significant and positive effect on perceived public journalism opportunities. In addition, as the close relations of journalists with their social environments and the number of interactions increased, it was found that the average of social capital and public journalism opportunities increased. In this context, it is understood that social capital has an important role in public journalism practices, and participating in social solidarity and communication networks facilitates pro-social journalism practices.

Keywords: Journalism, Social Capital, Public Journalism. 


\section{Giriş}

Gazetecilik kurumunun 'dördüncü kuvvet' olarak kamu adına denetleme yaptığı șeklindeki söylemler sıklıkla eleștirilmektedir. Bu eleștiriler; gazetecilik kurumunun işlevlerinin sorgulanmasına ve gazetecilere olan güvenin sarsılmasına yol açmaktadır. Diğer yandan gazetecilik alanına yönelik eleștiri ve analizler, çoğunlukla siyasal ve ekonomik değişkenler üzerine yoğunlaşmakta, toplumsal değişkenler ve gazeteciliğin iç dinamikleri çoğunlukla analizlere dahil edilmemektedir. Bu sebeple çalışmada sosyal sermaye, gazetecilerin içinde bulundukları toplumsal bağlam ve koşulların incelenmesinde önem arz eden yaklaşımlardan biri olarak değerlendirilmektedir.

Sosyal sermaye, bireysel ve toplumsal olmak üzere iki farklı gerçeklik düzleminde incelenebilir. Buna göre; bireysel düzlemde sosyal sermaye, bireylerin sahip oldukları ilișkilere ve bu ilișkilerin kendilerine sağladığı avantajlara gönderme yaparken (Baker, 1990; Bourdieu ve Wacquant, 1992; Burt, 1992; Belliveau, O'Reilly ve Wade, 1996; Portes, 1998; Knoke, 1999; Lin, 2010); toplumsal düzlemde ise, yaşanılan bölgedeki komşuluk ilişkilerinden yardımlaşma düşüncesine, sivil toplum kuruluşlarından dernekleşme faaliyetlerine kadar bir dizi sivil katılım biçiminin toplumsal hayata sağladığı katkılara gönderme yapan bir kaynak (Coleman, 1990; Fukuyama, 1995; Putnam, 1995; Thomas, 1996; Brehm ve Rahm, 1997) olarak kabul edilmektedir.

Dolayısıyla çalıșmanın çıkış noktası, gazetecilik alanıyla sosyal sermaye yaklaşımı arasındaki ilişkiyi anlama ve açıklama çabalarından kaynaklanmaktadır. Çalışmada, gazetecilik alanıyla sosyal sermaye arasında çok boyutlu bir ilișki varsayılmıștır. Zira gazeteciler, mesleki profesyonelliğin gerektirdiği biçimde toplumun farklı kesimlerinden insanlarla etkileşime girmek ve gerektiğinde tekrar faydalanabilmek adına profesyonel ilişkiler tesis etmek durumundadırlar. Hatta öyle ki, gazetecilerin mesleklerini icra edebilmeleri için bireysel sosyal sermayelerinden yararlanmak durumunda bulundukları, aksi durumunda mesleğin icrasının mümkün olamayacağı şeklinde bir iddia ortaya atmak dahi mümkündür. Öte yandan gazeteciler, ürettikleri ve sundukları içerikler dolayısıyla sivil katılıma ya da çekilmeye de etki ettiklerinden, sosyal sermayenin toplumsal düzlemdeki sivil katılım boyutu daha da önemli hale gelmektedir.

Bu bağlamda, sosyal sermaye yaklaşımının önde gelen isimlerinden Putnam (2000), kitle iletişiminin (özellikle televizyon izleme) boş zaman etkinliklerini doldurmasıyla sivil katılımdaki azalma arasında önemli bir ilişki kurmuştur. Ayrıca, çeşitli gazetecilik pratiklerinin sosyal sermaye üzerindeki etkileriyle ilgilenen kimi araştırmalara (Wallack, 2000; Stevens, Alger, Allen ve Sullivan, 2006; Richards, Chia ve Bowd, 2011; Richards, 2012; Mercado, 2015; Washburn ve Raynauld, 2016) rastlanabilmektedir.

$\mathrm{Bu}$ çalışmada ise 'gazetecilik kurumunun sosyal sermayeye ne yaptığı?' sorusundan ziyade, 'sahada çalıșan gazeteci aktörlerin sosyal sermayeyle ne yaptığı?' sorusunun cevabı aranmaktadır. Mesleki pratikleri gereği, toplumu kamusal alanda gerçekleşen sivil katılıma teşvik edecek olan bir gazetecinin, bizatihi aktif bir yurttaş olması gerekmektedir. Dolayısıyla bu çalışmada, gazetecilerin sivil katılım davranışları sosyal sermaye yaklaşımının sunduğu kavramsal araçlar üzerinden araştırılmakta ve bu davranışların kamusal habercilik olanaklarına nasıl yansıdığı analiz edilmektedir.

Çalışmanın ele almaya çalıştığı temel problem, toplumsal düzlemde bireyler arasındaki ilişkiler ağının üretken faydalarına odaklanan sosyal sermayenin (Claridge, 2004), gazetecilik üretim pratiklerinde ve daha özelde kamusal habercilik olanaklarında 
bir etkisinin bulunup bulunmadığının teorik ve ampirik olarak cevaplanmasıdır. $\mathrm{Bu}$ bağlamda çalışmanın ortaya attığı ve ispatlamaya çalıştığı temel tez dar anlamda "sosyal sermayenin kamusal habercilik olanakları üzerinde olumlu bir etkisinin bulunduğu" yönündeki önermedir.

Literatür incelendiğinde, sosyoloji, ekonomi, iktisat gibi alanlarda ziyadesiyle bir öneme sahip bulunduğu görülen sosyal sermaye yaklaşımının; toplumsal ilişkilere, sosyal iletişim ağlarına ve sivil katılıma yaptığı vurgularla iletişim ve gazetecilik araștırmaları açısından da önemli olduğu rahatlıkla söylenebilir. Fakat Türkiye'de, sosyal sermaye ve sosyal medya arasındaki ilişkileri ele alan sınırlı sayıdaki araştırmalar (Babacan, 2012; Bakan, 2014; Acun vd., 2017; Boz, Buluk ve Aysu, 2017; Yıldız, 2017; Saltik, 2018; Keleş ve Akkaş, 2018; Baş, 2018; Aydın Öztürk, 2018; Eniç, 2018) hariç tutulduğunda, meseleyi gazetecilik düzeyinde tartışan herhangi bir çalışmaya rastlanmamıştır. Ancak, gazeteciliğin kurumsal olarak sıklıkla tartışmaların odağında kalarak aşınması, farklı analizlerin ve çözüm önerilerinin sunulmasını gerektirmektedir. Bu bakımdan çalışmanın, gazetecilerin içinde bulundukları toplumsal bağlam ve koşulları incelemesi nedeniyle önemli bir boşluğu doldurması beklenmektedir.

Anlatılanlar çerçevesinde, çalışmada öncelikle sosyal sermaye kavramı açıklanmakta ve gazetecilik alanı ve sosyal sermaye yaklaşımı arasındaki ilişkileri ele alan literatür kısaca incelenmektedir. Uygulama kısmında, gazeteciler ile gerçekleştirilen alan araştırmasının bulguları yer almaktadır. Sosyal sermaye, toplumsal dayanışma ağlarının ortaya çıkarttığı kaynaklar olarak ele alınmakta ve bu kaynakların kamusal habercilik olanaklarındaki rolü, çeşitli değişkenlerle birlikte serimlenmek istenmektedir. Bu amaçla İstanbul, Ankara ve İzmir başta olmak üzere Türkiye'nin farklı illerinden gazetecilerle gerçekleştirilen anket çalışmasından elde edilen bulgular yorumlanmaktadır. Sonuç kısmında, araştırmada elde edilen veriler değerlendirilmekte ve bazı öneriler sunulmaktadır.

\section{Sosyal Sermaye Kavramı}

Sosyal sermaye, sosyal bilimler alanının sık uğraklarından olan iki kavramın, "sosyal" ve "sermaye" kavramlarının bir araya getirilmesinden oluşan bir metafor olarak ortaya çıkmıştır. Ancak farklı disiplinlerden araştırmacıların bu metafora olan ilgisi ve yaptığ çalışmalar, kavramın kendisine sosyal bilimler içerisinde önemli bir çalışma alanı bulmasını sağlamıştır.

Sosyal bilimlerin pek çok kavramı gibi, sosyal sermayenin tanımlanmasında da tek ve nihai bir tanımın söz konusu olmadığını belirtmek gerekmektedir. Hatta konuyla ilgilenen teorisyen sayısı kadar, sosyal sermaye tanımı bulunduğu ileri sürülebilir. Tanımlamalarda belirli ölçüde farklılıklar bulunmakla birlikte, ortak bazı noktaların da bulunduğu belirtilmelidir.

$\mathrm{Bu}$ noktada sosyal sermayenin bazı önemli tanımları üzerinden açıklanması ve incelenmesi yerinde olacaktır. Baker sosyal sermayeyi, "aktörlerin belirli sosyal yapılardan türettikleri ve daha sonra çıkarları doğrultusunda kullandıkları bir kaynak" (1990, s. 619) olarak tanımlamaktadır. Bourdieu ve Wacquant ise, sosyal sermayeyi "birey veya grubun sahip olduğu az ya da çok kurumlaşmış ilişkilerinin oluşturduğu kalıcı iletişim ağından elde edilen güncel ve gerçek kaynaların toplamı" (1992, s. 119) olarak görmektedir. Sosyal sermaye konusunda bir diğer önemli isim Coleman ise sosyal sermayenin işleviyle tanımlandığını vurgulamaktadır. Ona göre sosyal sermaye, "sosyal yapının bazı görünümlerini meydana getirmekte ve yapı içindeki bireylerin belirli 
eylemlerini kolaylaştırmaktadır" (1990, s. 302). Fukuyama, "insanların gruplar ve örgütlerde ortak amaçlar için birlikte çalışma yeteneğini” (1995, s. 10) sosyal sermaye olarak tanımlamaktadır. Putnam ise, "iletişim ağları, normlar, toplumsal güven gibi ortak fayda için koordinasyonu ve iş birliğini kolaylaştıran toplumsal örgütlenmenin özelliklerini" (1995, s. 67) sosyal sermaye olarak tanımlamaktadır.

Genel olarak incelendiğinde, araştırmacıların disiplinlerine ve araştırma eğilimlerine bağlı olarak sosyal sermayenin farklı yönlerine vurgu yaptığı anlaşılmaktadır. Tanımlamaların sosyal sermayeyi; grup ya da örgüt içi süreçlerde, daha genel olarak toplumsal yapılarda ya da bunların her ikisinde birden iş gören bir kaynak olarak kabul ettiğini ifade etmek mümkündür. Ayrıca sosyal sermayenin ele alınmasında ve analiz edilmesinde de benzer farklılaşmaların söz konusu olduğunu belirtmek gerekmektedir (Adam ve Roncevic, 2003, s. 158; Şan ve Akyiğit, 2015, s. 126).

Literatürde söz konusu olan tanım çeşitliliği, sosyal sermayenin sahip olduğu bağlamsal özellik ile kavramsallaștırılması ve operasyonel hale getirilmesi konusundaki karmaşıklıklardan kaynaklanmaktadır. Ancak sosyal sermayenin tanımlanmasında bulunan en belirgin ortak yön, sosyal ilişkilerin üretken faydalarına odaklanılmasıdır (Claridge, 2004). Bu bağlamda sosyal sermaye; bireylerin gündelik hayatlarında mesleki ya da kişisel açıdan faydalandıkları, makro düzlemde ise toplumsal dayanışma ve iş birliğini kolaylaştıran bir kaynak olarak değerlendirilmektedir.

Dolayısıyla birey ya da toplum açısından önemli bir kaynak olarak değerlendirilen sosyal sermayenin; gazetecilik alanında nasıl iş gördügünün, gazeteci aktörlerin mesleki pratiklerinde bir yerinin bulunup bulunmadığının incelenmesi gerekmektedir.

\section{Gazetecilik Alanı ve Sosyal Sermaye İlişkisi}

Gazetecilik alanında yaşanan dönüşümlere karşın, alanla ilgili birtakım sorular gündemde kalmaya devam etmektedir. "Gazetecilik sistemi ile kamuoyu arasında nasıl bir ilişki vardır? Gazetecilik sisteminin ve kamuoyunun birbirleri için anlamı ve önemi nedir? Gazetecilik sisteminin toplumsal sistem üzerindeki etkisinin ölçüsü ve sinırları nedir?" (Alver, 2011, s. 462). Bu sorular dikkate alındığında, sosyal sermaye yaklaşımının, gazetecilik kurumu ile toplumun çeşitli kesimleri arasındaki ilişkiler açısından birtakım cevaplar vermesi muhtemeldir. Gazetecilik mesleğinin sunduğu içeriklerin sosyal sermaye üzerinde birtakım etkileri söz konusu olmakta, ayrıca gazeteciler işlerini yaparken sosyal sermayeden faydalanmaktadır.

Diğer yandan, sosyal sermaye "bireyler arasındaki iletişim ağlarından elde edilen kaynaklar" (Bourdieu ve Wacquant, 1992, s. 119) ya da "toplumu bir arada tutan yapıştırıcı" (Wallack, 2000, s. 340) ise, gazetecilik pratiklerinin bu kaynaklar ya da yapıştırıcı üzerinde birtakım etkileri söz konusudur. Sosyal sermayeyi toplumsal düzeyde bir analiz aracı olarak değerlendirdiğimizde ve sivil katılım, aktif yurttaşlık gibi unsurları sosyal sermaye göstergeleri olarak kabul ettiğimizde, gazeteciliğin bu alandaki rolü zımni olarak anlaşlabilmektedir.

Ancak literatür incelendiğinde bu ilişkinin sadece zımni düzeyde olmadığı, somut teorik katkıların söz konusu olduğu görülmektedir. Bu bağlamda sosyal sermaye literatürüyle önemli ölçüde ilişkilendirilen Tocqueville (2000), Amerika'da Demokrasi isimli eserinde basın ve sivil toplum arasında oldukça önemli ilişkiler kurmuştur. İnsanların ortak çıkarlara ulaşmak için bireysel olarak yapabilecekleri şeylerin sınırlı olduğunu, bunun ancak gazeteler yardımıyla mümkün olduğunu ifade etmiștir. 
Kitle iletişim araçlarının ve basının sosyal sermaye üzerindeki etkileri sivil ve siyasal katılım ile ilişkilendirildiğine, 'kamusal alan' konusu gündeme gelmektedir. Bilindiği gibi kamusal alan konusunda, Habermas'ın oldukça merkezi bir yeri bulunmaktadır. Kamusal alan kavramıyla "herşeyden önce, toplumsal yaşamımız içinde, kamuoyuna benzer bir şeyin oluşturulabildiği bir alanı" kastettiğini belirten Habermas (2004, s. 95), kamusal alanın genel yarara ilişkin meselelerde vatandaşların özgürce tartışabildikleri bir alan olduğunu, kitle iletişim araçlarının da kamusal alanın iletişim araçları olduğunu belirtmektedir. Dolayısıyla kamusal alan ve sosyal sermaye kavramsallaştırmaları açısından ortak paydanın "yurttaşlık" üzerine olduğu anlaşılmaktadır. Demokratik sistemin sürdürülmesi toplumsal meselelerle ilgilenen aktif yurttaşlara bağlanmakta, vatandaşların bu meselelerle ilgili bilgilendirilmesi ise kitle iletişim araçları tarafından gerçekleştirilmektedir. Bu bakımdan gazetecilik kurumu, sunduğu içeriklerle ortak faydaya yönelik toplumsal eylemleri kolaylaştıran sosyal sermayeye katkıda bulunmakta ya da zarar vermektedir.

$\mathrm{Bu}$ bağlamda, iletişim araştırmalarıyla sosyal sermaye literatürü arasındaki ilişkinin en somut hale geldiği nokta, Gerbner ve arkadaşlarının televizyon izleyiciliği üzerine yaptığı araştırmalara dayanmaktadır. Bilindiği gibi medya, pek çok olumsuz mesajı kitlelere aktarmaktadır. Kitleler, her gün medya tarafından gönderilen suç, şiddet, cinsellik gibi içeriklere maruz kalmaya devam etmektedir. Bu anlamda, Gerbner'in başlattığı "Kültürel Göstergeler" araştırma projesi ve "Ekme Kuramı" olarak bilinen yaklaşım (Yaylagül, 2013, s. 74-77), medyanın sosyal sermaye üzerindeki olumsuz etkilerini ifade etmek açısından öne çıkmaktadır. Yapılan televizyon araştırmaları neticesinde, izleyicilerde "Vasat Dünya Sendromu" olarak adlandırdıkları bir durumun ortaya çıktığını ileri sürülmüştür (Gerbner, Gross, Morgan ve Signorielli ,1980, s. 17, 24; Gerbner, Morgan, Signorielli ve Shanahan, 2002, s. 52). Bu görüşe göre televizyon, izleyicilerde tehlike ve güvensizliğe ilişkin genel bir anlam ekmektedir (Gerbner ve Gross, 1976, s. 191). Cinayet, hırsızlık, savaș, tecavüz haberleri gibi içerikler, bireylerin yaşadıkları dünya hakkında olumsuz genellemeler yapmalarına neden olmaktadır

Gerbner ve arkadaşlarının çalışmalarından önemli ölçüde yararlanan Putnam (2000), kitle iletişimiyle sosyal sermaye arasındaki ilişkiyi detaylı biçimde incelemektedir. Putnam televizyonu kullanan bireylerin değișen boş zaman etkinlikleri ve bu nedenle bireyin toplumsal yaşamdan çekilmesi üzerinden sosyal sermayeyi analiz etmektedir. Ancak haber okuyuculuğu/izleyiciliği, sivil topluma katılım ve aktif yurttaşlık açısından olumlu bir gösterge olarak ele alınmaktadır.

Gazetecilik alanıyla sosyal sermaye ilişkisinin değerlendirilebileceği bir diğer isim Pierre Bourdieu'dur. Sosyal sermaye literatürüyle ilișkilendirilen Bourdieu (1997), gazetecilik alanı açısından da önemli bir yer işgal etmektedir. Özellikle televizyon ve gazetecilik konusundaki görüşlerini topladığı Televizyon Üzerine isimli kitabı, bu anlamda öne çıkmaktadır. Bu bağlamda toplumsal yapıyı farklı alanların meydana getirdiğini ifade eden düşünür, gazeteciliği bu alanlardan biri olarak ele almaktadır. Bourdieu sosyolojisiyle değerlendirildiğinde, alandaki gazeteci aktörlerin diğer sermaye biçimleriyle birlikte (ekonomik, kültürel, simgesel vb.) sosyal sermayeyi kullandıklarını söylemek mümkün hale gelmektedir.

Öte yandan sosyal sermayenin; internet gazeteciliği, vatandaş gazeteciliği, kamusal gazetecilik, yerel gazetecilik gibi farklı yönelimler açısından incelendiği çalışmalar da bulunmaktadır. Wallack, kamusal gazetecilik projeleri ve bu projelerin sosyal sermaye 
açısından taşıdığı öneme dikkat çekmektedir (2000, s. 350). Antonieta Mercado (2015), Amerika'da bulunan Meksikalı göçmenler üzerine yaptığı çalışmada, sosyal sermaye ve toplum yanlısı gazetecilik pratikleri arasında önemli bir bağlantı kurmaktadır. Richards (2012) ise, yerel gazetecilik ve sosyal sermaye arasındaki ilişkiyi araştırmıştır. Yerel toplulukların iletişim ve karşılıklı anlayışlarını geliştirme yoluyla yerel medyanın bölgesel sosyal sermayeye nasıl katkıda bulunduğu üzerinde durmuştur (Richards, 2012, s. 627). Sosyal sermaye ve yerel medya ilişkisi üzerinde duran bir diğer çalışma Stevens ve arkadaşları (2006, s. 61) tarafından Minnesota şehrinde gerçekleştirilmiştir. Sivil katılım, kulüp ve dernek üyelikleri, seçimlere katılım gibi sosyal sermaye göstergelerinin oldukça yüksek olduğu Minnesota'da, yerel haberlerin ağırlıklı olarak bölge sorunlarıyla ilgili olduğu varsayımı sınanmıştır. Richards, Chia ve Bowd, yerel toplulukların sosyal sermayesinde, yerel medyanın rolünü araştırdıkları çalışmalarında ortaya çıkan en önemli unsurun "karşılıklılık" olduğunu vurgulamışlardır (2011, s. 103). Hiper-yerel medya (hyperlocal websites) üzerinde yaptıkları çalışmada Metzgar, Kurpius ve Rowley (2011, s. 772), bu organizasyonların hem interaktif medya yoluyla toplumsal katılımın vitrini durumuna geldiği, hem de kamusal faydayı merkeze alan gazetecilik pratiklerini arttırdığı sonucuna ulaşmıștır. Diğer yandan Washburn ve Raynauld (2016), Kanada'da toplum yanlısı gazetecilik yapan kuruluşları incelemişlerdir. Haber medyasının hizmet ettiği topluluğun, kültürel ve sosyal kimliğini yansıtma rolünün, reklam endüstrisi ve bazı ekonomik ilişkiler nedeniyle azaldığını vurgulamışlardır (Washburn \& Raynauld, 2016, s. 230).

Bu bağlamda gazetecilik alanıyla sosya sermaye yaklaşımı arasında teorik ve pratik açıdan çok boyutlu ilişkiler kurmak mümkün hale gelmektedir. Sosyal sermayenin temel unsurları olarak değerlerndirilen güven, normlar ve iletişim ağları gazetecilik pratikleri açısından oldukça değerlidir. Gazeteciler, toplumsal yapının farklı alanlarındaki insanlarla güvene ve karşılıklılık normlarına dayalı ilişkiler geliștirmek ve iletişim ağlarından yararlanmak durumundadır. Gazeteci aktörler; medya kuruluşları, meslektaşları, okuyucuları, haber kaynakları, siyasetçiler, iş adamları, ünlüler ve sivil toplum gibi sosyal yapının oldukça geniş bir kesimiyle ilişkiler geliştirmektedir. Dolayısıyla sosyal sermayenin gazetecilik alanı açısından oldukça önemli bir kaynak olduğu düşünülmekte ve bu düşüncenin ampirik olarak sınanması gerekmektedir.

\section{Yöntem}

Çalışmada, gazetecilerin sosyal sermayeleriyle, mesleki sorumluluklarından biri olan kamusal habercilik arasındaki ilişkinin incelenmesi amaçlanmıştır. Toplumsal dayanışma ağları olarak ele alınan sosyal sermaye, gazetecilerin mesleki pratiklerinde yararlandıkları kaynaklar olarak değerlendirilmekte ve sosyal sermayenin, gazetecilerin algıladıkları kamusal habercilik olanakları üzerindeki rolü araştırılmaktadır.

\subsection{Evren ve Örneklem}

Çalışmanın evrenini, Türkiye'de gazetecilik mesleğini sürdürenler oluşturmaktadır. Türkiye İstatistik Kurumu (TÜİK, 2015) istatistiklerine göre, Türkiye'de 2015 yılı itibariyle 16.885 televizyon, 2.725 radyo çalışanı bulunmaktadır. Basın İlan Kurumu (BİK, 2018) istatistiklerine göre ise, 2018 yılı itibariyle resmi ilan yayınlama hakkına haiz gazetelerde 8.683 fikir işçisi çalışmaktadır. Resmi veriler gazete, radyo ve televizyonlarda yaklaşık olarak 29.000 kişinin çalıştığını göstermektedir. Ancak bu çalışan sayısının içinde, gazeteci olmayanlarında yer aldığı belirtilmelidir. Ayrıca alanda kayıt dışı olarak çalışan/ çalıştırılan çok sayıda gazeteci bulunmaktadır. Diğer yandan sigortalı olarak çalıştırılan 
birçok kişi, ilgili kanunlar çerçevesinde sigortalanmamaktadır. Sarı basın kartı sahipliği de tam sayının belirlenmesinde bir gösterge olarak değerlendirilememektedir. Bu sayının içinde, aktif olarak gazetecilik yapmayan, hatta gazetecilikle ilgisi bulunmayan çok sayıda kişinin bulunduğu bilinmektedir. Bağımsız olarak faaliyetlerini sürdüren gazeteciler de hesaba katıldığında, tam sayı belirlenememektedir.

İfade edilen güçlükler doğrultusunda, Türkiye'de gazetecilik mesleğini sürdürenlere ilişkin olarak, ancak yaklaşık bir tahmin vermek mümkün olmaktadır. $\mathrm{Bu}$ nedenle çalışmada; evren tahmini olarak 100 bin kişi olarak belirlenmiş ve kolayda örnekleme yöntemi kullanılmıştır. 0.05 anlamlılık düzeyinin sağlanması için 384 gazeteci araștırma örneklemine dahil edilmiştir. Örneklem grubun, gazetecilik faaliyetlerinin kapsamına göre (ulusal, bölgesel, yerel) dengeli bir dağılım göstermesine çalışılmıştır. Örneklemin temsil kabiliyetini arttırmak amacıyla; geleneksel/konvansiyonel medyanın en güçlü olduğu ve sayısal olarak en fazla gazetecinin çalıştığı İstanbul, Ankara ve İzmir illerine ağırlık verilmiş, diğer illerde gazetecilik yapan aktörler de örneklemde yer almıştır.

\section{2. Ölçüm Araçları ve Kullanılan Testler}

Saha araştırmasında, yüz yüze anket tekniği kullanılmıştır. Anket formunda, bağımlıbağımsız değişkenler ile gazetecilerin iletişim ağlarının özelliklerini ölçmeye yönelik sorular oluşturulmuştur. Bu bağlamda çalışmanın bağımlı değişkeni "algılanan kamusal habercilik olanakları", bağımsız değișken ise "algılanan sosyal sermaye" şeklindedir.

Gazeteci aktörlerin algıladıkları sosyal sermayeyi ölçmeye yönelik, Onxy ve Bullen (2000) tarafından geliştirilen ve Ardahan (2012) tarafından Türk toplumuna geçerlilik ve güvenilirlik çalışması gerçekleştirilen Sosyal Sermaye Ölçeği kullanılmıştır. Orijinal ölçek 34 madde ve 12 faktörden oluşurken, Ardahan (2012, s. 774) yaptığı geçerlilik ve güvenilirlik çalışması sonucu ölçeği 28 madde ve 9 faktör olarak yeniden yapılandırmıştır. Çalışmada katılımcıların ifadelere, orijinal ölçeğe uygun olarak 4'lü likert tipinde (1= Kesinlikle Hayır, 2=Sıklıkla Hayır, 3=Sıklıkla Evet, 4=Kesinlikle Evet) cevap vermeleri istenmiştir.

Gazetecilerin iletişim ağlarının özellikleri ve kamusal haber üretme olanakları, Yang (2016) tarafından kullanılan ifade ve sorulardan yararlanılarak ölçülmüştür. Gazetecilerin iletişim ağlarının özelliklerini tespit etmek amacıyla sosyal çevreyle (aile, arkadaşlar, meslektaşlar, komşular, diğer) yakınlıklarını, " $1=$ Hiç ilişkimiz yok" ve " $5=$ Çok yakınız" aralığında derecelendirmeleri istenmiştir. Ayrıca katılımcıların, sosyal çevrelerinden düzenli olarak etkileşime geçtikleri kişi sayısını, "Hiç" ve "5 ve üstü" aralığında belirtmeleri sağlanmıştır. Kamusal habercilik olanak/özgürlüklerine ilişkin algılamaları ölçmek için, genel kamusal yarara yönelik haber yapabilme olanakları ve farklı kaynakları (işletmeler, kamu görevlileri, iş insanları, STK temsilcileri, uzmanlar) kamu yararına haberler üretirken ne düzeyde kullanabildiklerini ifade etmeleri istenmiştir. Katılımcıların ifadeleri 5'li likert tipinde (1=Çok zor, 2=Zor, 3=Ne Zor Ne Kolay 4=Kolay 5=Çok kolay) cevaplamaları istenmiştir.

Kullanılan ölçeklerin ve alt boyutlarının çarpıklık değerleri 1,118 ile -0,611, basıklık değerleri ise 0,753 ile $-0,863$ arasında gerçekleșmiştir. Bu değerler normal dağılıma uymuş olup (George ve Mallery, 2010; Tabachnick ve Fidell, 2013), bu puanların bazı değişkenlere göre farklılık gösterme durumu parametrik olan test tekniklerinden $\mathrm{t}$ ve ANOVA testleri ile analiz edilmiştir. ANOVA testinde fark çıkması durumunda, farkı 
yaratan grubun belirlenmesi amacıyla Tukey testi yapılmıştır. Sosyal sermayenin, kamusal habercilik olanaklarına etkisi regresyon testi ile analiz edilmiştir.

\subsection{Güvenilirlik ve Yapı Geçerliliği}

Araştırma soruları ve hipotezlerini destekleyen bulguların değerlendirilmesinden önce, çalışmada kullanılan ölçeklere ilişkin yapı geçerliliği ve güvenilirlik analizlerine yer verilmektedir.

Kamusal habercilik olanaklarına ilişkin ifadeler, çeşitli analizlerde kullanmak amacıyla ölçek haline getirilmiştir. Ölçeğin yapı geçerliğinin belirlenmesi amacıyla, açımlayıcı faktör analizi (AFA) gerçekleștirilmiș, güvenirliğinin belirlenmesi amacıyla Cronbach's alfa güvenirlik katsayıları hesaplanmıştır.

Kamusal habercilik olanaklarına ilişkin ölçek (KHO) için yapılan analizde KMO değeri 0,866 olarak hesaplanmıştır. Buna göre örneklem sayısı faktör analizi için uygundur (KMO>0,500). Bartlett testi kapsamında X2 değeri 1809,135 ve istatistiksel olarak anlamlı bulunmuştur $(\mathrm{p}<0,05)$. KMO ve Bartlett testi sonucuna göre, verilerin faktör analizi için uygun olduğu sonucuna ulaşılmıştır. Buna göre, kamusal habercilik olanaklarına ilişkin oluşturulan ifadelere faktör analizi uygulanmıștır. Ayrıca ölçeğin faktör yapısının belirlenmesi amacıyla öz değerlerin saçılımını gösteren Scree Plot grafiği incelenmiştir. Yapılan faktör analizi sonucuna göre binişiklik nedeniyle 4. ve 12.madde ölçekten çlkarılmış olup, ölçeğin 11 madde ve iki boyuttan oluştuğu ('Genel Kamusal Boyut' ve 'Haber Aktörlerinin Aktarımı') belirlenmiştir. Ölçeğin toplam varyansı açıklama oranı \%59,216; güvenirlik katsayısı 0,872'dir. Buna göre ölçeğin güvenirlik düzeyi çok yüksektir.

Sosyal sermayeyi ölçmek için ise, Onyx ve Bullen (2000) tarafından geliştirilen ve Ardahan (2012) tarafından Türk toplumuna adaptasyon çalışması gerçekleştirilen ölçek kullanılmıștır. Ardahan (2012, s. 773) tarafından, ilgili çalışmada ölçeğin "yeni hali ile Cronbach's Alpha katsayısı 0.711" şeklinde ifade edilmektedir. Ayrıca bu haliyle ölçeğin istatistiki açıdan yeterli ve güvenilir olduğu vurgulanmaktadır. Bu çalışmada kullanılan Sosyal Sermaye Ölçeği'nin güvenilirlik katsayısı (Cronbach's Alpha) ise, 0,821 olarak hesaplanmıştır.

Ayrıca çalışmada ölçeklerin faktör yapısının doğrulanması ve uyum değerlerinin hesaplanması amacıyla doğrulayıcı faktör analizi (DFA) yapılmıştır. DFA, oluşturulan kuramsal çerçeveden "destek alarak" belirlenen değişkenlerin faktörler (gizil değişkenler) haline getirilerek elde edilen "verilerle ne derece uyum gösterdiğini değerlendirmeye yönelik bir analizdir." (Sümer, 2000, s. 52).

DFA'da test edilen modelin yeterliğinin anlaşılabilmesi için, farklı uyum indeksleri kullanılmaktadır. En fazla kullanılan uyum indeksleri; Ki-Kare Uyum Testi (ChiSquare Goodness), İyilik Uyum İndeksi (GFI), Düzeltilmiş İyilik Uyum İndeksi (AGFI), Karşılaştırmalı Uyum İndeksi (CFI), Normlaştırılmış Uyum İndeksi (NFI), Ortalama Hataların Karekökü (RMR veya RMS) ve Yaklaşık Hataların Ortalama Karekökü (RMSEA) şeklinde sıralanabilir (Cole, 1987, s. 585-586; Sümer, 2000, s. 59-62; Büyüköztürk, Akgün, Özkahveci, ve Demirel, 2004, s. 217). Bu çalışmada kullanılan uyum indeksleri ve kabul edilebilir değerleri; $\chi 2 / \mathrm{sd}<5$, CFI $>0,90, \mathrm{AGFI}>0.90, \mathrm{CFI}>0.90$, RMSEA $<0.08$, RMR $<0.08$ (Hooper, Coughlan ve Mullen, 2008, 53-55; Çapık, 2014, s. 199; Schumacker ve Lomax, 2015, 112-117) şeklindedir. 
Sosyal Sermaye Ölçeği için yapılan DFA analizinde, $\chi 2 /$ sd $(2,434)$, RMSEA $(0,061)$ ve RMR $(0,046)$ değerlerinin kabul edilebilir uyum indekslerini sağladığı, GFI $(0,890)$, CFI $(0,822)$ ve AGFI $(0,851)$ indekslerinin kabul edilebilir uyum indekslerine yakın olduğu ve kabul edildiği anlaşılmıştır. Uyum indeksleri sağlanması amacıyla hata terimleri arasında modifikasyonlar yapılmıştır.

Kamusal habercilik olanaklarını ölçmeye yönelik geliştirilen ölçeğe yapılan DFA analizinde, $\chi 2 /$ sd $(4,633)$, GFI $(0,929)$, CFI $(0,920)$ ve RMR $(0,066)$ değerlerinin kabul edilebilir uyum indekslerini sağladığ görülmekte iken AGFI $(0,881)$ ve RMSEA $(0,097)$ indekslerinin kabul edilebilir uyum indekslerine yakın olduğu ve kabul edildiği görülmektedir. Uyum indeksleri sağlanması amacıyla hata terimleri arasında modifikasyonlar yapılmıştır.

Ölçek ve ifadelere ilişkin güvenilirlik analizleri ve yapı geçerliliği, yukarıdaki biçimde özetlenebilir. Bu bağlamda çalışmada kullanılan ölçüm araçlarının güvenilir ve geçerli olduğunu söylemek mümkündür.

\subsection{Hipotez ve Araştırma Soruları}

Çalışmanın merkezinde, sosyal sermayenin kamusal habercilik olanakları üzerinde bir etkisinin bulunup bulunmadığının araştırılması vardır. Bu çalışmada, yapılan literatür incelemesi doğrultusunda, sosyal sermayenin gazetecilik pratikleri üzerinde bazı etkilerinin söz konusu olması beklenmektedir. Bu etkilerin araştırılması için, gazeteciliğin temel sorumlulukları arasında yer alan kamusal habercilik anlayışı temel alınarak, sosyal sermaye ve kamusal habercilik olanakları arasındaki ilişki araştırılmaktadır. Bu doğrultuda aşağıdaki hipotezin sınanması amaçlanmaktadır:

H1: Sosyal sermayenin kamusal habercilik olanakları üzerinde pozitif yönlü ve anlamlı bir etkisi vardır.

Ayrıca, çalışma çerçevesinde ele alınan araştırma soruları aşağıdaki gibidir:

AS.1: Gazetecilerin sosyal çevreleriyle yakınlık derecelerine göre algıladıkları sosyal sermayelerinde ve kamusal habercilik olanaklarında bir farklılaşma bulunmakta mıdır?

AS2: Gazetecilerin sosyal çevreleriyle etkileşim sayılarına göre algıladıkları sosyal sermayelerinde ve kamusal habercilik olanaklarında bir farklılaşma bulunmakta mıdır?

\section{Bulgular ve Yorum}

Bulgu ve yorumlar; gazetecilerin iletişim ağlarıyla ilgili betimleyici istatistikler, sosyal sermayenin kamusal habercilik olanaklarına etkisinin incelendiği regresyon modelleri ve gazetecilerin iletişim ağlarının özelliklerine göre, sosyal sermaye ve kamusal habercilik olanaklarında gerçekleșen farklılaşmalardan oluşmaktadır.

\subsection{Gazetecilerin İletişim Ağlarına İlişkin Betimleyici İstatistikler}

Gazetecilerin sosyal çevreleriyle iletişim ve ilişkilerini betimlemek amacıyla bazı sorular yöneltilmiştir. İlgili veriler ve analizleri aşağıda yer almaktadır. 
Tablo 1: Sosyal Çevreyle Yakınlık Derecesi

\begin{tabular}{|l|c|c|c|c|c|c|c|c|c|c|}
\hline \multirow{2}{*}{} & \multicolumn{2}{|c|}{ Hiç ilişkimiz yok } & \multicolumn{2}{|c|}{ Uzağız } & \multicolumn{2}{c|}{$\begin{array}{c}\text { Ne yakınız } \\
\text { ne uzağız }\end{array}$} & \multicolumn{2}{c|}{ Yakınız } & \multicolumn{2}{c|}{ Çok yakınız } \\
\cline { 2 - 11 } & $\mathbf{n}$ & $\%$ & $\mathbf{n}$ & $\%$ & $\mathbf{N}$ & $\mathbf{\%}$ & $\mathbf{n}$ & $\%$ & $\mathbf{n}$ & $\%$ \\
\hline Aile & 0 & 0,0 & 0 & 0,0 & 4 & 1,0 & 86 & 22,4 & 294 & 76,6 \\
\hline Arkadaşlar & 1 & 0,3 & 1 & 0,3 & 97 & 25,3 & 172 & 44,8 & 113 & 29,4 \\
\hline Meslektaşlar & 2 & 0,5 & 8 & 2,1 & 95 & 24,7 & 213 & 55,5 & 66 & 17,2 \\
\hline Komşular & 33 & 8,6 & 82 & 21,4 & 144 & 37,5 & 103 & 26,8 & 22 & 5,7 \\
\hline Diğer & 5 & 3,8 & 12 & 9,0 & 21 & 15,8 & 44 & 33,1 & 51 & 38,3 \\
\hline
\end{tabular}

Gazetecilerin 'aile', 'arkadaşlar', 'meslektaşlar', 'komşular' ve 'diğer' olmak üzere beş sosyal grupla yakınlık derecelerini belirtmeleri istenmiștir. Buna göre katılımcıların çoğunluğunun aile ilişkilerini çok güçlü şekilde $(\% 76,6)$ tanımladıkları anlaşılmaktadır. Yine arkadaş çevresi (yakınız=\%44,8, çok yakınız=29,4) ve meslektaşlarla (yakınız=\%55,5, çok yakınız=\%17,2) yakın ilişki içinde olduklarını belirtmişlerdir. Dikkat çekici bir sonuç olarak, verilen sosyal gruplar içerisinde gazetecilerin en uzak ilişkilerinin komşularıyla (hiç ilişkimiz yok=\%8,6, çok uzağız=\%21,4, ne yakınız ne uzağız=\%37,5) olduğu anlaşılmaktadır. Ayrıca 'diğer' seçeneği içerisinden yer alan insanlarla katılımcıların \%70’ten fazlasının yakın ve çok yakın ilişkiler kurduğu görülmektedir (Tablo 1).

Tablo 2: Sosyal Çevreden Her gün Etkileşime Girilen Kişi Sayısı

\begin{tabular}{|l|c|c|c|c|c|c|c|c|c|c|c|c|}
\hline \multirow{2}{*}{} & \multicolumn{2}{|c|}{ Hiç } & \multicolumn{2}{c|}{ 1 Kişi } & \multicolumn{2}{c|}{ 2 Kişi } & \multicolumn{2}{c|}{ 3 Kişi } & \multicolumn{2}{c|}{ 4 Kişi } & \multicolumn{2}{c|}{ 5 ve üstü } \\
\cline { 2 - 14 } & $\mathbf{n}$ & $\mathbf{\%}$ & $\mathbf{n}$ & $\mathbf{\%}$ & $\mathbf{n}$ & $\mathbf{\%}$ & $\mathbf{n}$ & $\mathbf{\%}$ & $\mathbf{n}$ & $\mathbf{\%}$ & $\mathbf{N}$ & \% \\
\hline Aile & 2 &, 5 & 51 & 13,3 & 34 & 8,9 & 46 & 12,0 & 63 & 16,4 & 188 & 49,0 \\
\hline Arkadaşlar & 2 &, 5 & 4 & 1,0 & 44 & 11,5 & 67 & 17,4 & 83 & 21,6 & 184 & 47,9 \\
\hline Meslektaşlar & 5 & 1,3 & 37 & 9,6 & 49 & 12,8 & 45 & 11,7 & 75 & 19,5 & 173 & 45,1 \\
\hline Komşular & 121 & 31,5 & 102 & 26,6 & 75 & 19,5 & 25 & 6,5 & 25 & 6,5 & 36 & 9,4 \\
\hline Diğer & 39 & 29,1 & 9 & 6,7 & 19 & 14,2 & 37 & 27,6 & 23 & 17,2 & 7 & 5,2 \\
\hline
\end{tabular}

Katılımclardan ailesinden her gün 5 ve daha fazla kişi ile etkileşime girenlerin oranı \%49,0; arkadaşlarından 5 ve daha fazla kişi ile etkileşime girenlerin oranı $\% 47,9$; meslektaşlarından 5 ve daha fazla kişi ile etkileşime girenlerin oranı \%45,1; komşularından hiçbiriyle etkileşime girmeyenlerin oranı \%31,5; diğer kişilerden hiçbiriyle etkileşime girmeyenlerin oranı \%29,1'dir. Bu bağlamda katılımcıların önemli bir kısmının aile, arkadaşlar ve meslektaşlardan çok sayıda insan ile etkileşime girdiği anlaşılmaktadır. En az etkileşime girilen sosyal grup ise 'komşular' şeklindedir. (Tablo 2).

Tablo 3: Sosyal Çevreden Haber Üretiminde Yararlı Bilgiler Sağlayanlar

\begin{tabular}{|l|c|c|c|c|c|c|c|c|c|c|c|c|}
\hline \multirow{2}{*}{} & \multicolumn{2}{|c|}{ Hiç } & \multicolumn{2}{c|}{ 1 Kişi } & \multicolumn{2}{c|}{ 2 Kişi } & \multicolumn{2}{c|}{ 3 Kişi } & \multicolumn{2}{c|}{ 4 Kişi } & \multicolumn{2}{c|}{ 5 ve üstü } \\
\cline { 2 - 14 } & $\mathbf{n}$ & $\mathbf{\%}$ & $\mathbf{n}$ & $\mathbf{\%}$ & $\mathbf{n}$ & $\mathbf{\%}$ & $\mathbf{n}$ & $\mathbf{\%}$ & $\mathbf{N}$ & $\mathbf{\%}$ & $\mathbf{n}$ & \% \\
\hline Aile & 171 & 44,5 & 81 & 21,1 & 65 & 16,9 & 34 & 8,9 & 20 & 5,2 & 13 & 3,4 \\
\hline Arkadaşlar & 90 & 23,4 & 76 & 19,8 & 96 & 25,0 & 55 & 14,3 & 20 & 5,2 & 47 & 12,2 \\
\hline Meslektaşlar & 5 & 1,3 & 15 & 3,9 & 40 & 10,4 & 86 & 22,4 & 80 & 20,8 & 158 & 41,1 \\
\hline Komşular & 167 & 43,5 & 132 & 34,4 & 75 & 19,5 & 4 & 1,0 & 3 & 0,8 & 3 & 0,8 \\
\hline Diğer & 11 & 6,8 & 21 & 13,0 & 28 & 17,4 & 27 & 16,8 & 27 & 16,8 & 47 & 29,2 \\
\hline
\end{tabular}

Gazetecilerden, ilgili sosyal gruplardan 'haber üretimi için yararlı bilgiler sağlayan insanların sayısını' belirtmeleri de istenmiştir. Bu bağlamda katılımcıların \%44,5'i hiçbir aile üyesinin haber üretimi için yararlı bilgili sağlamadığını ifade etmiştir. Yine katılımcıların \%43,5'i komşularından haber üretimi için yararlı bilgi sağlayan hiçimse olmadığını belirtmektedir. Ayrıca katılımcıların \%23,4'ü arkadaşları arasında haber 
üretimi için yararlı bilgi sağlayan hiç kimse olmadığını ifade etmektedir. En fazla haber üretimi için yararlı bilgiler sağlayan insan sayısı meslektaşlar kategorisinde gerçekleşmiştir. Bunun yanı sıra, 'diğer' kategorisinde de ilgili ortalamalar bakımından görece yüksek bir dağılım sergilendiği anlaşılmaktadır (n=161). Haber üretimi için yararlı bilgi sağlayan kişi sayısının en düşük seyrettiği kategorinin 'komşular' olması ise oldukça dikkat çekicidir (Tablo 3). Bu bağlamda araştırmaya dahil olan gazetecilerin aile, meslektaşlar ve arkadaşlarıyla yakın ilişkiler geliştirmeleri ve etkileşim sayılarının fazla olmasına karşın, büyük bir çoğunluğunun ailelerini, arkadaşlarını ve komşularını haber kaynağı olarak daha az kullandıkları anlaşılmaktadır. Gazetecilerin haber kaynağı olarak en fazla başvurdukları grup, meslektaşlarıdır.

\subsection{Sosyal Sermayenin Kamusal Habercilik Olanaklarına Etkisinin İncelenmesi}

Sosyal sermayenin kamusal habercilik olanaklarındaki rolünü incelemek amacıyla üç regresyon modeli kurulmuştur. İlk iki model (Tablo 4 ve 5), sosyal sermaye alt boyutlarının kamusal habercilik olanaklarının alt boyutlarına etkisini, üçüncü model (Tablo 6) ise sosyal sermaye ölçeğinin genelinin kamusal habercilik olanakları ölçeğinin geneline etkisini incelemektedir.

Tablo 4: Sosyal Sermaye Alt Boyutlarının KHO Faktör 1'e Etkisi (Regresyon)

\begin{tabular}{|c|c|c|c|c|c|c|c|}
\hline Bağımlı Değ & Bağımsız Değ & $\mathbf{F}$ & $\mathbf{p}$ & B & $\mathbf{t}$ & $\mathbf{p}$ & $\mathbf{R}^{2}$ \\
\hline \multirow{9}{*}{$\begin{array}{l}\text { KHO } \\
\text { Faktör1 } \\
\text { (Genel } \\
\text { Kamusal } \\
\text { Boyut) }\end{array}$} & Yerel Komiteye Katılım & \multirow{9}{*}{33,422} & \multirow{9}{*}{,000 } & 244 & 3,436 &, $001^{*}$ & \multirow{9}{*}{,446 } \\
\hline & Komşuluk İlişkileri & & &,- 657 & $-7,085$ &, $000^{*}$ & \\
\hline & Bir Yere Aidiyet & & & ,312 & 2,442 &, $015^{\star}$ & \\
\hline & Başkalığa Tolerans & & & ,168 & ,884 & ,377 & \\
\hline & STK Üyeliği & & & ,028 & , 186 & ,853 & \\
\hline & Güven İnsan & & & 1,169 & 9,664 &, $000^{*}$ & \\
\hline & Güven Çevre & & & ,891 & 5,488 &, $000^{*}$ & \\
\hline & Sosyal Konularda İnisiyatif & & &,- 083 &,- 550 &, 582 & \\
\hline & Sosyal Temsilcilik & & &,- 167 &,- 825 & ,410 & \\
\hline
\end{tabular}

Sosyal sermaye alt boyutlarının KHO Faktör 1'e (Genel Kamusal Boyut) etkisinin incelenmesi amacıyla kurulmuş olan regresyon modeli anlamlıdır $(p<0,05)$. Yerel Komiteye Katılım, Bir Yere Aidiyet, Güven İnsan ve Güven Çevre KHO Faktör 1'i pozitif etkilemekte $(B=, 244 ; B=, 312 ; B=1,169 ; B=, 891)$ iken Komşuluk İlişkileri negatif etkilemektedir $(\mathrm{B}=-, 657)$. Kamusal habercilik olanaklarını en fazla etkileyen alt boyut 'Güven İnsan' iken en az etkileyen alt boyut 'Bir Yere Aidiyet'tir. Faktör1deki değişimin yaklaşık \%45’i; Yerel Komiteye Katılım, Bir Yere Aidiyet, Güven İnsan ve Güven Çevre ile Komşuluk İlişkileri tarafından açıklanmaktadır.

Tablo 5: Sosyal Sermaye Alt Boyutlarının KHO Faktör 2'ye Etkisi (Regresyon)

\begin{tabular}{|c|c|c|c|c|c|c|c|}
\hline Bağımlı Değ & Bağımsız Değ & $\mathbf{F}$ & $\mathbf{P}$ & B & $\mathbf{t}$ & $\mathbf{p}$ & $\mathbf{R}^{2}$ \\
\hline \multirow{9}{*}{$\begin{array}{l}\text { KHO } \\
\text { Faktör } 2 \\
\text { (Haber } \\
\text { Aktörlerinin } \\
\text { Aktarımı) }\end{array}$} & Yerel Komiteye Katılım & \multirow{9}{*}{25,785} & \multirow{9}{*}{,000 } & ,093 & 1,643 & ,101 & \multirow{9}{*}{,383 } \\
\hline & Komşuluk İlişkileri & & & ,273 & 3,681 &, $000^{*}$ & \\
\hline & Bir Yere Aidiyet & & &,- 198 & $-1,935$ & 054 & \\
\hline & Başkalığa Tolerans & & &,- 151 &,- 995 & ,320 & \\
\hline & STK Üyeliği & & & ,011 & ,095 & ,925 & \\
\hline & Güven İnsan & & & ,483 & 4,999 &, $000^{*}$ & \\
\hline & Güven Çevre & & &, 751 & 5,793 &, $000^{*}$ & \\
\hline & Sosyal Konularda İnsiyatif & & &, 594 & 4,946 &, $000^{*}$ & \\
\hline & Sosyal Temsilcilik & & & ,135 & ,831 & ,407 & \\
\hline
\end{tabular}


Sosyal sermaye alt boyutlarının KHO Faktör 2'ye (Haber Aktörlerinin Aktarımı) etkisinin incelenmesi amacıyla kurulmuş olan regresyon modeli anlamlıdır $(p<0,05)$. 'Komşuluk İlişkileri', 'Güven İnsan', 'Güven Çevre’ ve 'Sosyal Konularda İnisiyatif' alt boyutları, KHO Faktör 2'yi pozitif etkilemektedir $(B=, 273 ; B=, 483 ; B=, 751 ; B=, 594)$. En fazla etkileyen alt boyut 'Güven Çevre' iken en az etkileyen alt boyut 'Komşuluk İlişkileri'dir. KHO Faktör 2'deki değişimin yaklaşık \%38'i Komşuluk İlişkileri, Güven İnsan, Güven Çevre ve Sosyal Konularda İnisiyatif tarafından açıklanmaktadır.

Bu bağlamda, sosyal sermaye ölçeğinde yer alan altı alt boyutun (Yerel Komiteye Katılım, Komşuluk İlişkileri, Bir Yere Aidiyet, Güven İnsan, Güven Çevre, Sosyal Konularda İnisiyatif) kamusal habercilik olanaklarının alt boyutlarında (Genel Kamusal Boyut ve Haber Aktörlerinin Aktarımı) anlamlı bir etkisi olduğu tespit edilmiştir.

Gazeteci aktörün, toplumsal hayatı olumlu yönde etkileyecek "formal veya informal yerel yönetime katılımı” şeklinde açıklanan 'Yerel Komiteye Katılım', bulunulan bölgede gönüllülük esasına dayalı olarak sosyal fayda sağlamak amacını yansıtmaktadır (Onyx ve Bullen, 2000; Ardahan, 2010). Bu yapılar, doğrudan kamusal sorunların çözümlenmesine yönelik olduğundan, gazeteci aktörlerin bu tür formal ya da informal topluluklara katılımı, bölgedeki kamusal sorunlarla ilgili bilgilenme düzeylerini arttırmaktadır. Dolayısıyla, yerel yönetime katılımın kamusal sorunlarla ilgili bilgiye erişim olanaklarını arttırarak kamusal habercilik olanaklarını kolaylaştırdığı tahmin edilmektedir.

'Bir Yere Aidiyet' alt boyutu, 'Genel Kamusal Boyut' üzerinde pozitif etkide bulunmuştur. Çalışılan medya kuruluşuna aidiyetin, gazetecilerin genel kamusal sorunlarla ilişkili haber yapma olanaklarında olumlu bir etkisi söz konusu olmaktadır. Bu bağlamda medya kuruluşlarının, gazetecilerin mesleki pratiklerini çeşitli yollarla (haber odası sosyalleşmesi gibi) politikalarıyla uyumlu hale getirdikleri bilinmektedir (Browne, 2001; Harrison, 2008). Dolayısıyla kurumlarına aidiyet duyan gazetecilerin, medya kuruluşunun politikalarıyla uyumlu hale gelmelerinin genel kamusal boyut açısından bir çeşit konformizm oluşturduğu düşünülmektedir. Bu uyumlaşma süreci, hazır kaynaklardan gelen bilgilerin kullanılmasına ve gazetecilerin kamusal habercilik olanaklarını kısmen kolay algılamalarına neden olabilmektedir.

Gazetecilerin diğer insanlara ve topluma duyduğu inanç ve bağlanma düzeyini ifade eden 'Güven İnsan' (Onyx ve Bullen, 2000; Ardahan, 2010) alt boyutunun, kamusal habercilik olanaklarının her iki alt boyutunu da olumlu etkilemesi son derece anlamlıdır. Gazeteciliğin temel dinamiği, toplumdaki diğer insanlarla etkileşimlere ve bilgi akışına dayanmaktadır. Dolayısıyla, gazetecilik faaliyetlerinin haber kaynaklarıyla güven temelli ilişkiler kurmaksızın mümkün olamayacağı hatırlandığında (Schudson, 2003; Tokgöz, 2008; White, 2008), insanlara olan güvenin, kamusal habercilik olanakları üzerindeki olumlu etkisi anlamlı hale gelmektedir.

Kamusal habercilik olanaklarının her iki alt boyutu üzerinde olumlu etkisi bulunan bir diğer sosyal sermaye alt boyutunun 'Güven Çevre' olduğu görülmektedir. Gazeteci aktörün, "yaşadığı yerdeki mahalleyi, çevreyi güvenilir bulması" (Onyx ve Bullen, 2000; Ardahan, 2010) şeklinde açıllanan 'Güven Çevre' sosyal sermaye literatürü açısından oldukça önemli bir alt boyuttur. Bir bölgedeki suç oranlarının fazlalığı, çok sayıda yasadışı faaliyetin söz konusu olması, sosyal sermaye erozyonuna yol açan unsurlardan biri olarak değerlendirilebilir (Park ve Burgess, 1921; Burgess, 1928; Sampson, Raudensbush ve Earls, 1997; Kawachi, Kennedy ve Wilkinson, 1999; Kızmaz, 2012; Karakuş, 2013). Bu bağlamda bu tür kanun dışı fiiller 'Güven Çevre' alt boyutuyla açıklanan algılamalara 
zarar vermektedir. Diğer taraftan suç oranlarındaki artış, suç örgütleri, çeteler gibi yapılanmaların fazlalığı, doğal olarak kamusal habercilik olanaklarını zorlaștırmaktadır. Gazeteciliğin en fazla meslek ölümlerinin yaşandığı, şiddetin sıklıkla söz konusu olduğu alanlardan birisi olduğu hatırlanacak olursa (Fleeson, 2000; Feinstein, 2006; White A., 2008; Yılmaz, 2015), suç oranlarının yüksek olduğu bölgelerde kamusal gazetecilik yapmanın son derece 'tehlikeli' ve 'zor' bir çaba olduğu somut bir gerçektir.

'Komşuluk İlişkileri' alt boyutunun, 'Genel Kamusal Boyut' üzerinde negatif bir etki oluşturması ise oldukça ilginçtir. Sosyal sermaye literatürü bakımından son derece kritik bir rolü bulunan komşuluk ilişkilerinin (Karagül ve Masca, 2005), toplumsal açıdan son derece önemli bir yeri vardır (Gündüz ve Yıldız, 2008; Özbay, 2014). Ancak şehir hayatının getirdiği yeni yaşam tarzlarının, komşuluk ilişkilerini zayıflatabilmektedir (Şensoy ve Karadağ, 2013). Ayrıca 'Komşuluk İlişkileri' boyutunun, 'Haber Aktörlerinin Aktarımı' üzerinde ise, pozitif bir etkisi bulunmasına karşın, bu etkinin zayıf düzeyde olduğu gözlenmiştir. Gazetecilerin iletişim ağlarının araştırıldığı kısımda da komşularla olan ilişkilerin sayısı ve yakınlığı diğer gruplara göre düşük çıkmıştır. Bu bağlamda, komşuluk ilişkileriyle ilgili oluşan olumsuz tablonun, sosyal yaşamdaki genel değişimle ilişkili olabileceği düşünülmektedir.

'Sosyal Konularda İnisiyatif alt boyutunun, 'Haber Aktörlerinin Aktarımı' üzerinde olumlu bir etkisi gözlenmiştir. Kamusal gazetecilik açısından bilgiye nereden ulaşabileceğini bilebilmek ve önüne gelen kamusal meselelerle alakalı istihbaratlarla ne yapacağ konusunda hızlı kararlar alabilmek (yani 'sosyal yapı için inisiyatif almak') hayati bir önem taşımaktadır. 'Sosyal Konularda İnisiyatif' (Onyx ve Bullen, 2000; Ardahan, 2010) alt boyutunun, kamusal habercilik olanakları üzerindeki olumlu etkisi bu bağlamda değerlendirildiğinde, böyle özelliklere sahip olan gazetecilerin (Yücedoğan, 1998; Browne, 2001; White T., 2005) kamusal sorunlarla ilgili istihbaratlara ulaşabilmeleri ve sosyal yapı adına habere dönüştürme refleksi göstermelerinin daha kolay olduğu söylenebilir.

Tablo 6: Sosyal Sermayenin Kamusal Habercilik Olanaklarına Etkisi (Regresyon)

\begin{tabular}{|l|l|c|c|c|c|c|c|}
\hline Bağımlı Değ & Bağımsız Değ & $\mathbf{F}$ & $\mathbf{p}$ & $\mathbf{B}$ & $\mathbf{T}$ & $\mathbf{p}$ & $\mathbf{R}^{\mathbf{2}}$ \\
\hline $\begin{array}{l}\text { Kamusal Habercilik } \\
\text { Olanakları }\end{array}$ & Sosyal Sermaye & 153,661 &, 000 &, 458 & 12,396 &, 000 &, 287 \\
\hline
\end{tabular}

Sosyal sermayenin kamusal habercilik olanaklarına etkisinin incelenmesi amacıyla üçüncü bir regresyon modeli kurulmuştur. Kurulan modelin anlamlı olduğu anlaşılmıștır $(\mathrm{p}<0,05)$. Üçüncü regresyon modelinin de önceki analizleri desteklediği görülmektedir. Sosyal sermaye, kamusal habercilik olanaklarını pozitif etkilemekte $(B=, 458)$ ve kamusal habercilik olanaklarındaki değişimin yaklaşık \%29'u, beklenen şekilde sosyal sermaye tarafından açıklanmaktadır. Kurulan regresyon modeli çerçevesinde, kamusal habercilik olanaklarının yaklaşık \%71'lik kısmının ise, çalışılan medya kuruluşunun politikaları, ekonomik ve siyasal değişkenler gibi unsurlarla açıklanabileceği tahmin edilmektedir.

\subsection{Sosyal Sermaye ve Kamusal Habercilik Olanaklarının İletişim Ağları Açısından İncelenmesi}

Gazetecilerin sahip olmaları gereken özellikler açıklanırken, iletişim ağlarının önemi çeşitli yönlerden vurgulanmaktadır (Browne, 2001; Tokgöz, 2008; White T., 2005). Ayrıca sosyal sermaye literatüründe de iletişim ağlarının önemi üzerinde durulmaktadır (Portes, 1998; Dasgupta, 2007; Field, 2008). Bu nedenle gazetecilerin iletişim ağları araştırılmış, sosyal çevreleriyle (aile, arkadaşlar, meslektaşlar, komşular, diğer) yakınlıkları ve etkileşim 
sayıları, sosyal sermaye ve kamusal habercilik olanakları açısından incelenmiştir. İlgili analizler ve yorumları aşağıda yer almaktadır.

Tablo 7: Sosyal Sermayenin Sosyal Çevreyle Yakınlık Derecesi Açısından İncelenmesi

\begin{tabular}{|c|c|c|c|c|c|c|c|}
\hline \multirow{19}{*}{ Sosyal Sermaye } & Aile & n & Ortalama & ss & $\mathbf{t}$ & $\mathbf{p}$ & \\
\hline & İlişkimiz var & 86 & 68,41 & 10,37 & \multirow{2}{*}{$-3,265$} & \multirow{2}{*}{$001^{*}$} & \\
\hline & Çok yakınız & 294 & 72,21 & 9,24 & & & \\
\hline & Arkadaşlar & n & Ortalama & ss & $\mathbf{F}$ & $\mathbf{p}$ & İkili Fark \\
\hline & İlişkimiz ne var ne yok & 97 & 69,14 & 7,22 & \multirow{3}{*}{5,957} & \multirow{3}{*}{,003* } & \\
\hline & İlişkimiz var & 172 & 71,04 & 8,82 & & & $1-3$ \\
\hline & Çok yakınız & 113 & 73,63 & 11,91 & & & \\
\hline & Meslektaşlar & $\mathbf{n}$ & Ortalama & ss & $\mathbf{F}$ & $\mathbf{p}$ & İkili Fark \\
\hline & Hiç ilişkimiz yok/ilişkimiz yok & 10 & 59,40 & 8,29 & \multirow{4}{*}{16,499} & \multirow{4}{*}{,000* } & $1-2$ \\
\hline & İlişkimiz ne var ne yok & 95 & 67,44 & 8,56 & & & $1-3$ \\
\hline & İlişkimiz var & 213 & 72,46 & 8,61 & & & $\begin{array}{l}1-4 \\
2-3\end{array}$ \\
\hline & Çok yakınız & 66 & 75,11 & 11,12 & & & $2-4$ \\
\hline & Komşular & n & Ortalama & ss & $\mathbf{F}$ & $\mathbf{p}$ & İkili Fark \\
\hline & Hiç ilişkimiz yok & 33 & 63,30 & 11,68 & \multirow{5}{*}{18,392} & \multirow{5}{*}{,000* } & $1-2$ \\
\hline & İlişkimiz yok & 82 & 68,71 & 8,43 & & & \\
\hline & İlişkimiz ne var ne yok & 144 & 70,50 & 7,66 & & & $\begin{array}{l}1-4 \\
1-5\end{array}$ \\
\hline & İlişkimiz var & 103 & 75,80 & 9,22 & & & $2-4$ \\
\hline & Çok yakınız & 22 & 77,73 & 10,72 & & & $2-5$ \\
\hline & & & & & & & $3-5$ \\
\hline
\end{tabular}

Tablo 7 incelendiğinde, dört sosyal grupla yakınlık derecesine göre gazetecilerin sosyal sermaye ortalamalarında anlamlı farklılaşmalar olduğu anlaşılmaktadır $(\mathrm{p}<0,05)$. Buna göre, gazetecilerin her bir sosyal gruptan insanlarla (aile, arkadaşlar, meslektaşlar, komşular) yakınlık dereceleri arttıkça, sosyal sermayelerinde bir artış söz konusu olmaktadır.

Tablo 8: Sosyal Sermayenin Sosyal Çevreyle Etkileşim Açısından İncelenmesi

\begin{tabular}{|c|c|c|c|c|c|c|c|}
\hline \multirow{11}{*}{$\begin{array}{l}\text { Sosyal } \\
\text { Sermaye }\end{array}$} & Aile & $n$ & Ortalama & ss & $\mathbf{F}$ & p & İkili Fark \\
\hline & 1 Kişi & 51 & 67,69 & 7,31 & \multirow{5}{*}{6,429} & \multirow{5}{*}{, $000^{*}$} & \\
\hline & 2 Kişi & 34 & 71,97 & 9,42 & & & $1-5$ \\
\hline & 3 Kişi & 46 & 68,74 & 10,79 & & & $3-5$ \\
\hline & 4 Kişi & 63 & 69,25 & 8,78 & & & $4-5$ \\
\hline & 5 ve üstü & 188 & 73,60 & 9,60 & & & \\
\hline & Arkadaşlar & $\mathbf{n}$ & Ortalama & ss & $\mathbf{F}$ & p & İkili Fark \\
\hline & 1-2 Kişi & 48 & 66,38 & 8,77 & \multirow{4}{*}{19,861} & \multirow{4}{*}{, $000^{\star}$} & $1-4$ \\
\hline & 3 Kişi & 67 & 69,85 & 6,88 & & & $2-4$ \\
\hline & 4 Kişi & 83 & 67,52 & 10,51 & & & $3-4$ \\
\hline & 5 ve üstü & 184 & 74,85 & 8,96 & & & \\
\hline
\end{tabular}




\begin{tabular}{|c|c|c|c|c|c|c|c|}
\hline \multirow{13}{*}{$\begin{array}{l}\text { Sosyal } \\
\text { Sermaye }\end{array}$} & Meslektaşlar & $\mathbf{n}$ & Ortalama & ss & $\mathbf{F}$ & $\mathbf{p}$ & İkili Fark \\
\hline & 1 Kişi & 37 & 64,27 & 8,29 & \multirow{5}{*}{8,822} & \multirow{5}{*}{, $000^{\star}$} & $1-2$ \\
\hline & 2 Kişi & 49 & 71,57 & 10,16 & & & $1-4$ \\
\hline & 3 Kişi & 45 & 69,27 & 10,47 & & & $1-5$ \\
\hline & 4 Kişi & 75 & 71,19 & 7,19 & & & $3-5$ \\
\hline & 5 ve üstü & 173 & 73,66 & 9,47 & & & \\
\hline & Komşular & $\mathbf{n}$ & Ortalama & ss & $\mathbf{F}$ & $\mathbf{p}$ & İkili Fark \\
\hline & Hiç & 121 & 68,00 & 9,32 & \multirow{6}{*}{10,622} & \multirow{6}{*}{, $000^{\star}$} & $1-3$ \\
\hline & 1 Kişi & 102 & 70,03 & 9,23 & & & $1-4$ \\
\hline & 2 Kişi & 75 & 72,49 & 6,86 & & & $1-5$ \\
\hline & 3 Kişi & 25 & 74,80 & 6,93 & & & $1-6$ \\
\hline & 4 Kişi & 25 & 79,84 & 8,38 & & & $2-5$ \\
\hline & 5 ve üstü & 36 & 75,50 & 12,68 & & & $2-6$ \\
\hline
\end{tabular}

Tablo 8 gazetecilerin sosyal çevreyle etkileşim sayılarına göre, sosyal sermayelerinde gerçekleşen farklılaşmaları yansıtmaktadır. Buna göre dört sosyal grup içinde, etkileşime girilen kişi sayısına göre anlamlı farklılaşmalar tespit edilmiştir $(\mathrm{p}<0,05)$. Belirtilen sosyal gruplarla daha az sayıda etkileşime giren gazetecilerin, sosyal sermaye ortalamalarının daha düşük olduğu gözlenmektedir. İlgili gruplar arasındaki ikili farklar incelendiğinde, etkileşim sayısı arttıkça sosyal sermaye ortalamalarının yükseldiği anlaşılmaktadır.

Tablo 9: Kamusal Habercilik Olanaklarının Sosyal Çevreyle Yakınlık Açısından İncelenmesi

\begin{tabular}{|c|c|c|c|c|c|c|c|}
\hline \multirow{15}{*}{ Кно } & Arkadaşlar & $\mathbf{n}$ & Ortalama & ss & $\mathbf{F}$ & $\mathbf{p}$ & İkili Fark \\
\hline & $\begin{array}{l}\text { İlişkimiz ne } \\
\text { var ne yok }\end{array}$ & 97 & 31,87 & 6,52 & \multirow{3}{*}{7,298} & \multirow{3}{*}{, $001^{*}$} & \\
\hline & İlişkimiz var & 172 & 35,77 & 6,66 & & & $1-2$ \\
\hline & Çok yakınız & 113 & 34,04 & 10,83 & & & \\
\hline & Meslektaşlar & n & Ortalama & ss & $\mathbf{F}$ & p & İkili Fark \\
\hline & $\begin{array}{l}\text { Hiç ilişkimiz yok/ } \\
\text { İlişkimiz yok }\end{array}$ & 10 & 29,20 & 3,71 & \multirow{4}{*}{14,169} & \multirow{4}{*}{, $000^{\star}$} & $1-3$ \\
\hline & $\begin{array}{l}\text { İlişkimiz ne } \\
\text { var ne yok }\end{array}$ & 95 & 30,42 & 6,57 & & & $2-3$ \\
\hline & İlişkimiz var & 213 & 36,35 & 7,20 & & & $2-4$ \\
\hline & Çok yakınız & 66 & 33,86 & 11,11 & & & \\
\hline & Komşular & $\mathbf{n}$ & Ortalama & ss & $\mathbf{F}$ & $\mathbf{p}$ & İkili Fark \\
\hline & Hiç ilişkimiz yok & 33 & 27,70 & 8,39 & \multirow{5}{*}{7,525} & \multirow{5}{*}{, $000^{\star}$} & $1-2$ \\
\hline & İlişkimiz yok & 82 & 33,52 & 9,09 & & & $1-3$ \\
\hline & $\begin{array}{l}\text { İlişkimiz ne } \\
\text { var ne yok }\end{array}$ & 144 & 34,67 & 7,44 & & & $1-4$ \\
\hline & İlişkimiz var & 103 & 36,19 & 7,10 & & & $1-5$ \\
\hline & Çok yakınız & 22 & 35,27 & 9,44 & & & \\
\hline
\end{tabular}

Tablo 9, sosyal çevreyle yakınlık derecesine göre kamusal habercilik olanaklarındaki farklılaşmaları yansıtmaktadır. Buna göre, aile ile yakınlık derecesine göre kamusal habercilik olanaklarında anlamlı bir farklılaşmaya rastlanamamıştır $(p>0,05)$. İkili farklara göre; arkadaș, meslektaş ve komşularıyla daha yakın bir ilișki tanımlayanların, kamusal habercilik ortalamalarının daha yüksek olduğu anlaşılmaktadır. 
Tablo 10: Kamusal Habercilik Olanaklarının Sosyal Çevreyle Etkileşim Açısından İncelenmesi

\begin{tabular}{|c|c|c|c|c|c|c|c|}
\hline \multirow{11}{*}{ КHO } & Arkadaşlar & N & Ortalama & ss & $\mathbf{F}$ & p & İkili Fark \\
\hline & 1-2 Kişi & 48 & 31,88 & 6,51 & \multirow{4}{*}{10,087} & \multirow{4}{*}{, $000^{\star}$} & $1-4$ \\
\hline & 3 Kişi & 67 & 30,67 & 6,14 & & & $2-3$ \\
\hline & 4 Kişi & 83 & 34,07 & 7,37 & & & $2-4$ \\
\hline & 5 ve üstü & 184 & 36,29 & 8,99 & & & \\
\hline & Meslektaşlar & $\mathbf{N}$ & Ortalama & ss & $\mathbf{F}$ & $\mathbf{p}$ & İkili Fark \\
\hline & $1 \mathrm{Kişi}$ & 37 & 31,57 & 4,56 & \multirow{5}{*}{4,663} & \multirow{5}{*}{, $001^{*}$} & $1-3$ \\
\hline & 2 Kişi & 49 & 31,16 & 9,32 & & & $1-4$ \\
\hline & 3 Kişi & 45 & 36,51 & 6,99 & & & $2-3$ \\
\hline & 4 Kişi & 75 & 36,04 & 8,29 & & & $2-4$ \\
\hline & 5 ve üstü & 173 & 34,53 & 8,42 & & & \\
\hline
\end{tabular}

Tablo 10, sosyal çevreyle etkileşim sayısına göre kamusal habercilik olanaklarında gerçekleşen farklılaşmaları yansıtmaktadır. Buna göre, aile ve komşularla etkileşim sayısına göre kamusal habercilik olanaklarında anlamlı bir farklılaşma tespit edilememiştir $(p>0,05)$. Arkadaşlar ve meslektaşlarla etkileşim sayısına göre ise, kamusal habercilik olanaklarında anlamlı farklılaşmalar bulunmaktadır. İkili farklar incelendiğinde; ilgili sosyal gruplardan etkileşime girilen insan sayısı arttıkça, kamusal habercilik olanakları ortalamalarında da bir artış gözlenmektedir.

$\mathrm{Bu}$ doğrultuda aile, arkadaşlar, meslektaşlar ve komşular olarak sıralanan dört sosyal grup ile daha yakın ilişkileri bulunduğunu belirten gazetecilerin, sosyal sermayeleri ve kamusal habercilik olanaklarıyla ilgili algılamaları daha yüksektir (Tablo 7 ve 9). Ayrıca, bu dört sosyal grup içerisinden daha fazla sayıda insanla etkileşime girdiğini belirten gazetecilerin, sosyal sermaye ve kamusal habercilik olanakları itibariyle genellikle daha yüksek ortalamalara sahip oldukları anlaşılmıştır (Tablo 8 ve 10). Dolayısıyla, farklı çevrelerden insanlarla daha yoğun ve sayısal olarak fazla olan etkileşim, toplumsal dayanışma ağlarına daha fazla katılımı temsil etmekte, aynı zamanda kamusal habercilik olanaklarını kolaylaștırmaktadır. Ancak sosyal çevreyle yakınlıkları ve etkileşim sayılarına göre sergilenen olumlu tabloya rağmen, gazetecilerin sosyal çevreleri içinde yer alan aile, arkadaşlar ve komşularını haber kaynağı olarak daha az kullandıkları tespit edilmiştir. Haber üretimi için yararlı bilgilerin sağlandığı grup olarak 'meslektaşların' ciddi oranda öne çıktığı anlaşılmaktadır (Tablo 3). Bu durum, Bourdieu (1997)'nun gazetecilik alanına ilişkin ortaya attığı 'alan etkisi' düşüncesini yansıtmaktadır. Haber üretimiyle ilgili bilgi akışının ağırlıklı olarak meslektaşlardan sağlanması, tipik bir alan etkisi olarak yorumlanabilir. Ayrıca, haber üretimi için yararlı bilgi sağlayan 'diğer' tanıdıkların (aile, arkadaşlar ve komşulara göre) sayısının, oransal olarak daha fazla olduğu izlenmiștir (Tablo 3). Dolayısıyla çalışmada yer alan gazetecilerin, haber üretiminde, nispeten uzak ve mesafeli olarak tanımlanabilecek ilişkilerini (meslektaşlar ve diğer kategorisi) daha fazla kullandıklarını söyleyebilmek mümkün hale gelmektedir. Bu durum Granovetter (1973)'ın vurguladığı 'zayıf bağların gücü' ve Burt (1992, 2001)'un üzerinde durduğu 'yapısal boşluklar' düşüncesiyle paralellik göstermektedir. Enformasyon akışı, güçlü bağlardan ziyade zayıf bağlar üzerinde gerçekleşmekte ve görece zayıf bağlantılar kuran bireyler, gruplar arasında oluşan yapısal boşluklarda gerçekleșen enformasyon akışından daha fazla avantaj sağlayabilmektedir. Bu bağlamda, gazetecilerin mesleki pratiklerinde daha çok, görece zayıf olan bağları kullandıkları tahmin edilmektedir. 


\section{Sonuç ve Öneriler}

Gazetecilik alanının, toplumsal faydaya dayanan hareket noktasından uzaklaştığı yönündeki tartışmalar sürmektedir. Gazetecilik alanındaki bu tartışmalar, kendi varlık alanını tehdit eden varoluşsal bir krizi işaret etmektedir. Bu krizin arka planında ekonomik, siyasi ve sosyal ilişkiler yumağının doğurduğu birtakım sorunların olduğu bilinmektedir.

Bu bağlamda, çalışmanın çıkış noktası, gazetecilik alanının analizinde, iki önemli kavramın önemli bir katkı sağlayabileceği düşüncesidir. Bu kavramlar; sosyal sermaye ve kamusal gazetecilik anlayışlarıdır. Gazetecilik alanındaki incelemelere, birbirinden beslenen bu iki düşüncenin katkı sağlayıp sağlayamayacağının kuram ve pratikte sınanması gereklilik halini almıştır.

Ortaya çıkan gereklilikten hareketle gerçekleştirilen literatür incelemesi, gazetecilik alanı ve sosyal sermaye arasındaki somut ve zımni ilişkileri ortaya koymaktadır. Sosyal sermaye yaklaşımında yer alan kimi kuramcıların bu ilişkiye belirgin bir biçimde göndermede bulunduğu anlașılmaktadır. $\mathrm{Bu}$ anlamda, 'kitle iletişiminin, sosyal medyanın veya gazetecilik pratiklerinin sosyal sermayeye ne yaptı̆̆ı?' sorusuna cevap arayan birçok çalışma da mevcuttur. Ayrıca yurttaş gazeteciliği, yerel gazetecilik ya da kamusal gazetecilik yönelimleri bağlamında sosyal sermayeyi inceleyen araștırmalar da bulunmaktadır.

İlgili çalışmalar, çeşitli iletişim ya da etkileşim biçimlerinin toplumsal dayanışma ağlarını ifade eden sosyal sermaye üzerinde az ya da çok olumlu ya da olumsuz birtakım etkilerinin söz konusu olduğunu göstermektedir. Boş zaman etkinliklerinin, televizyon izleme davranışlarıyla doldurulması ya da medyanın sunduğu şiddet, korku vb. içerikli mesajların, sosyal sermaye üzerindeki olumsuz etkileri üzerinde duran araștırmaların yanı sıra, medyanın ve gazetecilik kurumunun sunduğu sivil katılıma yönelik içeriklerin 'aktif vatandaşlar' oluşturmaya yönelik olumlu etkileri üzerinde duran çalışmalar da mevcuttur.

$\mathrm{Bu}$ çalışma, gazetecilerin sosyal sermaye olarak adlandırılan toplumsal dayanışma ağlarından, mesleki açıdan ne ölçüde yararlandığını araştırması bakımından bahsedilen çalışmalardan ayrılmaktadır. Dolayısıyla çalışmada, yukarıda belirtilen soru tersine çevrilmiş ve 'gazeteciler sosyal sermayeyle ne yapmaktadır? şeklinde düzenlenmiștir. Çünkü gazetecilik alanı ile sosyal sermaye arasında bir karşılıklı bağımlılık söz konusudur. Gazetecilik kurumu, sosyal sermayeyi olumlu ya da olumsuz etkilediği gibi ondan etkilenmekte ve beslenmektedir.

Bu noktada kamusal gazetecilik vurgusu, belirtilen karşılıklı bağımlılığın araştırılmasında öne çıkmaktadır. Gazetecilik, özü itibariyle, kamusal faydaya odaklanan toplumsal bir pratiktir. Ancak başta bahsedilen sorunlar, gazeteciliğe yüklenen tarihsel sorumlulukların yerine getirilmesini engellemektedir. Aslında kamusal gazetecilik anlayışı, gazetecilik kurumuna zaten yüklenmiş olan tarihsel sorumluluğun hatırlatılmasıdır. Dolayısıyla kamusal gazetecilik kavramsallaștırması, gazetecilik pratiklerinde toplumsal fayda odaklı bir çözüm önerisi sunma çabasıdır.

Kamusal fayda odaklı habercilik düşüncesinin yansıması olan 'kamusal gazetecilik' toplumsal düzlemde incelenmesi gereken bir anlayıștır. Kamusal gazetecilik anlayışının gerçekleştirilebilmesinde, (siyasal ve ekonomik koşullar kadar) gazetecinin bulunduğu toplumsal bağlam ve koşulların da önemli bir rolü vardır. Bu çalışmada, toplumsal 
dayanışma ağları olarak incelenen sosyal sermaye, bu bağlam ve koşulların ortaya konulmasında önemli göstergelerden biri olarak ele alınmıştır. Dolayısıyla, 'sosyal doku içerisinde yer alan dayanışma ağlarının (sosyal sermayenin) durumunun, gazetecilerin kamusal habercilik olanaklarında önemli bir değişime neden olduğu' çalışmanın temel önermesi olarak değerlendirilmiş ve buna uygun şekilde hipotezler ve araştırma soruları geliştirilmiştir.

Özetlemek gerekirse, bu çalışmanın ele almaya çalıştığı kuramsal perspektif açısından uygulama kısmında elde edilen veriler doğrultusunda araştırma soruları cevaplanmış ve araştırmaya ilişkin hipotezlerin önemli ölçüde desteklendiği sonucuna ulaşılmıştır. Dolayısıyla sosyal sermaye toplumsal dayanışma ağları olarak düşünüldüğünde, kamusal gazetecilik anlayışı bu dayanışma ağlarından dikkate alınacak ölçüde beslenmektedir. Gazeteciliğin, demokratik kamusal alanlarda üstlenmesi gereken toplumsal fayda odaklı görev ve sorumluluklarını yerine getirebilmesi için, toplumsal dayanışma ağlarından beslenen kamusal gazetecilik anlayışının alanda hâkim kılınması gerekmektedir. Bunun için gerek alandaki gazeteci aktörler düzeyinde gerekse toplumsal düzlemde sosyal sermayeye yatırım stratejileri geliştirilmelidir. Bu yolla, gazetecilerin daha çeşitli kaynaklardan yararlanmaları ve daha fazla kamusal habercilik anlayışına yönelmeleri sağlanabileceği gibi, yurttaşların da gazetecilerden kamusal habercilik beklentileri arttırılarak toplumsal talep oluşturulabilir. Bunun için, gazeteci aktörlerin ve gazetecilik öğrencilerinin sivil toplum kuruluşlarına katılımlarının sağlanması, gazetecilerin mesleki örgütlenme (gazeteciler cemiyetleri, dernek ve sendikaları vb.) üyeliklerinin arttırılması gibi sosyal sermayeye yatırım stratejileri geliştirilebilir. Ayrıca; sivil toplum kuruluşları, vatandaşlar ve bölgedeki tüm paydaşlardan bilgi akışının sağlandığı, mikro ölçekli bağımsız gazetecilik hareketlerinin sayısının arttırılması hem sosyal sermayeyi arttırıcı hem de kamusal habercilik anlayıșını yaygınlaştırıcı bir yaklașım olarak değerlendirilebilir.

Sonuç olarak; sosyal sermaye, mevcut toplumsal sistemin doğurduğu birçok problemin analiz edilmesi adına önemli bir kavramsal araç olarak düşünülmelidir. Aynı sistem içerisinde yer alan medya ve gazetecilik alanlarında da benzer sorunların bulunduğu açıktır. Dolayısıyla gazetecilik/medya/iletişim alanlarında siyasal, ekonomik, kültürel vb. değișkenlerin yanında sosyal sermaye gibi toplumsal değişkenlerin de analizlere dahil edilmesi, farklı problem alanlarının incelenmesinde yeni perspektifler sağlayabilecektir. Bu nedenle sosyal sermayenin; kitle iletişimi, kişilerarası iletişim ve çevrimiçi etkileşim gibi konular açısından ve farklı analiz düzeylerinden incelenmesinin, alana zenginlik katacağı tahmin edilmektedir. Bilhassa, Türkiye'de kitle iletişimi ve çevrimiçi etkileşim biçimlerinin sosyal sermaye üzerindeki rolünün; bireylerin boş zaman etkinlikleri ve yalnızlaşma gibi konular üzerinden incelenmesi değer taşımaktadır.

\section{Kaynakça}

Acun, İ., Yücel, C., Balbağ, N. L., İri, S., ve Belenkuyu, C. (2017). Sosyal Sermaye ve Sosyal Medya: Demokrasi ve Vatandaşlık Hakkında Bir Araştırma. Sakarya University Journal of Education, 7(3), 564-583.

Adam, F., ve Roncevic, B. (2003). Social Capital: Recent Debates and Research Trends. Social Science Information, 42(2), 155-183.

Alver, F. (2011). Gazetecilik Bilimive Kuramları: Gazetecilik Kuram Tasarımlarını Türkiye'deki Gazetecilik Sistemi ve Uygulamalarıyla Sinanma Denemesi. İstanbul: Kalkedon. 
Ardahan, F. (2012). Sosyal Sermaye Ölçeği Geçerlilik ve Güvenilirlik Çalışması. International Journal of Sciences, 9(2), 773-789.

Aydın Öztürk, T. (2018). Social Capital, Relations and Music World: Networks in New Media. Journal of Economy Culture and Society, (58), 91-103.

Babacan, M. E. (2012). Toplumsal Paylaşım Ağlarında Sosyal Sermaye Pratikleri. Sakarya Üniversitesi Sosyal Bilimler Enstitüsü Sosyoloji Anabilim Dalı, Yayınlanmamış Doktora Tezi. Sakarya.

Bakan, U. (2014). Bireysel Farklılıkların Sosyal Sermaye Oluşumuna Etkisi: Facebook ve Linkedın Kullanıcıları Üzerine Karşılaştırmalı Bir Analiz. Ege Üniversitesi Sosyal Bilimler Enstitüsü Gazetecilik Anabilim Dalı, Yayınlanmamış Doktora Tezi. İzmir.

Baker, W. (1990). Market Networks and Corporate Behavior. American Journal of Sociology, 96, 589-625.

Basın İlan Kurumu. (2018). 2018 Yılı Basın Çalışanları İstatistikleri. Erişim adresi: http:// www.bik.gov.tr/wp-content/uploads/2018/08/Tablo-1.docx?x69656

Baş, F. C. (2018). Sosyal Medya Davranışının Oluşumu: Çevrimiçi Ortamlarda Güven, Sosyal Sermaye ve Saygınlık İlişkisi. Sosyoloji Araştırmaları Dergisi, (21) 2, 49-85.

Belliveau, M.A., O'Reilly, C.A. ve Wade, J.B. (1996). Social Capital at the Top: Effects of Social Similarity and Status on CEO Compensation. Academy of Management Journal, 39, 1568-1593.

Bourdieu, P. (1997). Televizyon Üzerine. (Çev. T. Ilgaz) İstanbul: Yapı Kredi Yayınları.

Bourdieu, P., ve Wacquant, L. J. (1992). An Invitation to Reflexive Sociology. Chicago: University of Chicago Press.

Boz, B., Buluk, B., ve Aysu, S. (2017). Sosyal Medya Kullanımı ve Sosyal Sermaye İlişkisi: Çanakkale Onsekiz Mart Üniversitesi Örneği. Uluslararası İktisadive İdari İncelemeler Dergisi, (16. UİK Özel Sayısı), 633-648.

Brehm, J., ve Rahn, W. (1997). Individual-Level Evidence for the Causes and Consequences of Social Capital. American Journal of Political Science, 41(3), 999-1023.

Browne, C. (2001). Gazetecinin El Kitabı. Ankara: Mediacat.

Burgess, E. W. (1928). The Growth of the City: An Introduction To A Research Project. R. E. Park, R. E. ve Burgess, E.W (Ed.), The City (ss. 47-62) içinde. Chicago: University of Chicago Press.

Burt, R. S. (1992). Structural Holes: The Social Structure of Competition. Cambridge: Harvard University Press.

Burt, R. S. (2001). Structural Holes Versus Network Closure As Social Capital. N. Lin, C. S. Cook ve R. S. Burt (Ed.), Social Capital: Theory and Research (ss. 31-56) içinde. New York: Routledge.

Büyüköztürk, Ș., Ö. E. Akgün, Ö. Özkahveci ve F. Demirel. (2004). Güdülenme ve Öğrenme Stratejileri Ölçeğinin Türkçe Formunun Geçerlik Güvenirlik Çalışması. Kuram ve Uygulamada Eğitim Bilimleri, 4(2), 207-239.

Claridge, T. (2004). Social Capital and Natural Resource Management: An important role for social capital?. Brisbane: University of Queensland. 
Cole, D. A. (1987). Utility of Confirmatory Factor Analysis in Test Validation Research. Journal of Consulting and Clinical Psychology, 55(4), 584-594.

Coleman, J. S. (1990). Foundations of Social Theory. Cambridge: Harvard University Press.

Çapık, C. (2014). Geçerlik ve Güvenirlik Çalıșmalarında Doğrulayıcı Faktör Analizinin Kullanımı. Anadolu Hemşirelik ve Sağlık Bilimleri Dergisi, 17 (3), 196-205.

Dasgupta, P. (2007). Economics: A Very Short Introduction. New York: Oxford University Press.

Eniç, D. (2018). Facebook Sosyal Sermayeyi Nasıl Etkiler?. Artıbilim: Adana Bilim ve Teknoloji Üniversitesi Sosyal Bilimler Dergisi, 1(1), 39-61.

Feinstein, A. (2006). Journalists Under Fire: The Psychological Hazards of Covering War. Baltimore: The Johns Hopkins University Press.

Field, J. (2008). Sosyal Sermaye (2. baskı). (B. Bilgen ve B. Şen, Çev.) İstanbul: İstanbul Bilgi Üniversitesi Yayınları.

Fleeson, L. (2000). Ten Steps to Investigative Reporting. Washington: ICFJ (International Center For Journalists).

Fukuyama, F. (1995). Trust: The Social Virtues and The Creation of Prosperity. New York: Free Press Paperbacks.

George, D. ve Mallery, P. (2010). SPSS for Windows Step by Step: A Simple Guide and Reference 17.0 Update (10th Edition). Boston: Pearson.

Gerbner, G., Gross, L., Morgan, M., \& Signorielli, N. (1980). The "Mainstreaming” of America: Violence Profile No: 11. Journal of Communication, 30(3), 10-29.

Gerbner, G., Morgan, M., Gross, L., Signorielli N. ve Shanahan. J. (2002). Growing Up with Television: Cultivation Processes. Jennings B. ve Zillmann D. (Ed.), Media Effects: Advances in Theory and Research (s. 43-68) içinde. New Jersey: Lawrence Erlbaum Associates.

Gerbner, G., ve Gross, L. (1976). Living with Television: The Violence Profile. Journal of Communication, 26 (2), 172-199.

Granovetter, M. (1973). The Strength of Weak Ties. American Journal of Sociology, 78 (6), 1360-1380.

Gündüz, M., ve Yıldız, M. C. (2008). Türk Yazılı Kültüründe Komşuluk. Elektronik Sosyal Bilimler Dergisi, 7(25), 123-138.

Habermas, J. (2004). Kamusal Alan. M. Özbek (Dü.) Kamusal Alan (s. 95-102) içinde. İstanbul: Hil Yayınları.

Harrison, J. (2008). Exploring news values: The ideal and the real. Chapman J. ve Kinsey M. (Ed.), Broadcast Journalism: A Critical Introduction (s. 60-68) içinde. Taylor \& Francis e-Library.

Hooper, D., Coughlan, J. ve Mullen, M. R. (2008). Structural Equation Modelling: Guidelines for Determining Model Fit. The Electronic Journal of Business Research Methods, 6(1), 53-60.

Karagül, M., ve Masca, M. (2005). Sosyal Sermaye Üzerine Bir İnceleme. Ekonomik ve Sosyal Araştırmalar Dergisi. 1, 37-52. 
Karakuş, Ö. (2013). Suç Korkusunun Sosyolojik Belirleyenleri: Sosyal Sermaye mi? Sosyal Kontrol mü?. Eskisehir Osmangazi Üniversitesi Sosyal Bilimler Dergisi, 14(1), 1-19.

Kawachi, I., Kennedy, B. P., ve Wilkinson, R. G. (1999). Crime: Social Disorganization And Relative Deprivation. Social science \& medicine, 48(6), 719-731.

Keleş, Ş., ve Akkaş, İ. (2018). Yaşam Memnuniyeti Sosyal Sermaye ve İletişim. Journal of Strategic Research in Social Science, 4(4), 109-122.

Kızmaz, Z. (2012). Gelişmekte Olan Ülkelerde Suç: Suç Oranlarının Artıșı Üzerine Sosyolojik Bir Çözümleme. Mukaddime, (5), 51-74.

Knoke D. (1999) Organizational Networks and Corporate Social Capital. Leenders R.T.A.J. ve Gabbay S.M. (Ed), Corporate Social Capital and Liability (ss. 17-42) içinde. Boston, MA: Springer.

Lin, N. (2010). Sosyal Sermaye Network Kuramının İnşası. Şahin M. M. ve Ünal A. Z. (Ed.), Sosyal Sermaye: Kuram Uygulama Eleștri (ss. 171-220) içinde. İstanbul: Değişim Yayınları.

Mercado, A. (2015). El Tequio: Social Capital, Civic Advocacy Journalism and the Construction of a Transnational Public Sphere by Mexican Indigenous Migrants in the US. Journalism, 16 (2), 238-256.

Metzgar, E., D. Kurpius ve K. Rowley. (2011). Defining Hyperlocal Media: Proposing a Framework for Discussion. New media \& Society, 5(13), 772-787.

Onyx J. ve P. Bullen. (2000). Measuring Social Capital in Five Communities. Journal of Applied Behavioral Science, 36 (1), 23-42.

Özbay, F. (2014). Akrabalık ve Komşuluk Illişkileri. Turğut M. ve Feyzioğlu S. (Ed.). Türkiye Aile Yapısı Araştırması Tespitler, Öneriler (s. 56-85) içinde. Ankara: Aile ve Sosyal Politikalar Bakanlığı Yayınları.

Park, R. E. ve Burgess, E. W. (1921). Introduction to Science of Sociology. Chicago: The University of Chicago Press.

Portes, A. (1998). Social Capital: Its Origins and Applications in Modern Sociology. Annual Review of Sociology, 24, s. 1-24.

Putnam, R. D. (2000). Bowling Alone: The Collapse and Revival Of American Community. New York: Simon \& Schuster.

Putnam, R. D. (1995). Bowling Alone: America's Declining Social Capital. Journal of Democracy, 6(1), 65-78.

Richards, I. (2012). Beyond City Limits: Regional Journalism and Social Capital.Journalism, 14 (5), s. 627-642.

Richards, I., Chia, J. ve Bowd, K. (2011). When Communities Communicate: Rural Media and Social Capital. Australian Journalism Review, 33 (1), 97-106.

Saltik, R. (2018). Sosyal Sermaye ve Armağan Ekonomisi Üzerinden Sosyal Medya ve Stalk Olgusu: Instagram Üzerinden Bir İnceleme. Akdeniz Üniversitesi İletişim Fakültesi Dergisi, (30), 345-363.

Sampson, R. J., Raudenbush, S. W. ve Earls, F. (1997). Neighborhoods And Violent Crime: A Multilevel Study Of Collective Efficacy. Science, 277(5328), 918-924. 
Schudson, M. (2003). The Sociolgy of News. New York: W.W. Norton.

Schumacker, E. R. ve Lomax, R. G. (2015). A Beginner Guide to Structural Equation Modeling (4th Edition). New York and London: Routledge.

Stevens, D., Alger, D., Allen B. ve Sullivan, J. L. (2006). Local News Coverage in a Social Capital: Election 2000 on Minnesota's Local News Stations. Political Communication, 23, 61-83.

Sümer, N. (2000). Yapısal Eşitlik Modelleri: Temel Kavramlar ve Örnek Uygulamalar. Türk Psikoloji Yazıları, 3, 49-74.

Şan, M. K. ve Akyiğit, H. (2015). Sosyal Sermaye Tartışmaları ve Türkiye'de Sosyal Sermayenin Ölçülmesi Sorunu. Selçuk Üniversitesi Sosyal Bilimler Enstitüsü Dergisi, (34), 123-134.

Şensoy, N.,veKaradağ,A.A. (2012). Sosyal Etkileșimin Komşuluk Düzeyinde Geliștirilmesine Yönelik Bir Araştırma: Ankara TOKİ Atakent Sitesi Örneği. Inönü Üniversitesi Sanat ve Tasarım Dergisi, 2(6), 279-289.

Tabachnick, B.G. ve Fidell, L.S. (2013). Using Multivariate Statistics (6th Edition). Boston: Pearson.

Thomas, C. (1996). Capital Markets, Financial Markets And Social Capital (An Essay on Economic Theory and Economic Ideas). Social and Economic Studies, 45(2/3), 1-23.

Tocqueville, A. (2000). Democracy in America. Chicago and London: The University of Chicago Press.

Tokgöz, O. (2008). Temel Gazetecilik. Ankara: İmge Kitabevi.

Türkiye İstatistik Kurumu. (2018). 2015 Ekonomik Faaliyete Göre İstihdam ve Personel Maliyeti [Radyo ve Televizyon Kurumları İstatistikleri]. Erişim adresi: http://tuik. gov.tr/PreIstatistikTablo.do?istab_id=410

Wallack, L. (2000). The Role of Mass Media in Creating Social Capital: A New Direction for Public Health. Smedley B. ve Syme S. (Ed), Promoting Health: Intervention Strategies from Social and Behavioral Research (s. 337-365) içinde. Washington D.C: National Academy Press.

Washburn, R., ve Raynauld, V. (2016). Journalism on the Ground in Rural Ontario. Gasher M., Brin C., Crowther C., King G., Salamon E.,ve Thibault S. (Ed.), Journalism in Crisis : Bridging Theory and Practice for Democratic Media Strategies in Canada (ss. 226249) içinde. Toronto, Bufallo, London: University of Toronto Press.

White, A. (2008). To Tell You Truth: The Ethical Journalism Initiative. Brussels: International Federation of Journalists.

White, T. (2005). Broadcast News Writing, Reporting, and Producing (Fourth Edition). Oxford: Focal Press.

Yang, L. (2016). News Sources of Citizen Journalists: How Does Social Capital Influence Citizen Journalists in China and United States. The University of Alabama Department of Journalism. Unpublished Doctoral Dissertation. Alabama.

Yaylagül, L. (2013). Kitle İletişim Kuramları. Ankara: Dipnot Yayınları.

Yıldız, M. (2017). İletişim Sürecinde Sosyal Medya ve Sosyal Sermaye. The Journal of Social Science, 2(1), 71-82. 
Yılmaz, Y. (2015). Türkiye'de Gazetecilik Mesleği. Ankara: Nobel.

Yücedoğan, G. (1998). Türkiye ve Fransa'da Gazeteci Kimliği Sorunu. İstanbul: İstanbul Üniversitesi İletişim Fakültesi Yayını. 


\title{
The Use of Social Solidarity Networks in Journalism: Investigation on the Role of Social Capital in Public Journalism
}

\author{
Ahmet Biçer (Res. Asst. Ph.D.) \\ Mustafa Koçer (Assoc. Prof. Dr.)
}

\section{Extended Abstract}

Social capital can be evaluated in two different reality aspects as individual and social. At the individual level, social capital is a resource derived from social relationships of actors and which they use for their purposes. At the social level, it is considered as a resource that expresses the contribution of several forms of civil participation to social life, from neighborhood relations in the area of living to mutual aids, from non-governmental organizations to association activities. Therefore, in the study it was assumed that journalists should use the social capital, which is a source derived from social structures and relations, in their professional practice. Considering this assumption, it was aimed to examine the role of social capital in the journalists' public journalism opportunities.

In line with the purposes of the study, journalists' social capital and the possibilities of public journalism were examined. The convenience sampling method was used, and a survey was conducted with a total of 384 journalists. In order to measure the social capital, the scale developed by Onxy and Bullen (2000) which was adapted to Turkish society by Ardahan (2010) were used. To investigate public journalism possibilities and communication networks, statements that Yang (2016) applied to journalists in China and the USA were used.

The regression analysis of the data obtained from the field study showed that five subdimensions of social capital (participation in the local community, work connections, trusting people, trusting environment, proactivity in a social context) had a statistically significant and positive effect on the factors of the public journalism opportunities scale. The sub-dimension of neighborhood connections had a negative effect on the first factor and a positive effect on the second factor of the public journalism opportunities scale. The third regression analysis that is examining the effect of the social capital scale on public journalism opportunities showed that there was a statistically significant $(\mathrm{p}<0.05)$ and a positive effect $(B=, 458)$. According to the relevant regression model, approximately $29 \%$ of the change in public journalism opportunities was explained by the social capital.

In addition, the communication networks of journalists were examined, and significant differences were identified in their social capital and public journalism opportunities. Accordingly, it was observed that, as the close relations of journalists with the social environment (family, friends, colleagues and neighbors) and the number of their interactions increased, their averages on social capital and public journalism opportunities were increased too. In this context, it was concluded that communication networks play an important role in public journalism opportunities and social capital and, communication networks increase pro-social journalism practices. However, it has been observed that journalists rarely use their family, friends and neighbors in their social circles as news sources. As a group where useful information was provided from for news production, it was understood that the colleagues came to prominence and this situation was in line with Bourdieu's (1997) 'field effect' suggested in his journalism analysis. On 
the other hand, in the use of journalists' social environment as news source, 'colleagues' and' other 'categories came to the forefront. The relevant data indicated that journalists use relatively remote and distant relationships rather than close relationships such as their family and friends in their professional practices. This was in line with Granovetter's (1973) "strength of weak ties" idea and Burt's $(1992,2001)$ "structural holes" idea which were emphasized in the social capital literature. In this context, it was estimated that the journalists participating in the research are using their relatively weak relationships in their professional practice.

Therefore, in terms of the theoretical perspective on which this study is based, the research questions were answered in line with the data obtained in the application section and it was concluded that the assumptions and hypotheses about the research were supported significantly. When social capital was considered as social solidarity networks, it was understood that the concept of public journalism is fueled noteworthily by these solidarity networks. In this connection, it was stated that investment strategies in social capital such as ensuring the participation of journalist actors and journalism students in non-governmental organizations, increasing the membership of journalists in professional organizations (such as journalist associations and unions) should be developed. Also, increasing the number of micro-scale independent journalistic movements, which provide information flow from non-governmental organizations, citizens and all stakeholders in the region, was proposed as an approach that both increases social capital and promotes public journalism.

Keywords: Journalism, Social Capital, Public Journalism. 